Prepared in cooperation with the Albuquerque Bernalillo County Water Utility Authority

\title{
Water-Level Data for the Albuquerque Basin and Adjacent Areas, Central New Mexico, Period of Record Through September 30, 2015
}

Data Series 1025

Version 1.1, August 2021 



\section{Water-Level Data for the Albuquerque Basin and Adjacent Areas, Central New Mexico, Period of Record Through September 30, 2015}

By Joseph E. Beman and Christina F. Bryant

Prepared in cooperation with the Albuquerque Bernalillo County Water Utility Authority

Data Series 1025

Version 1.1, August 2021 


\section{U.S. Geological Survey, Reston, Virginia First release: October 2016, online and in print Revised: August 2021 (ver. 1.1), online}

For more information on the USGS - the Federal source for science about the Earth, its natural and living resources, natural hazards, and the environment-visit https://www.usgs.gov or call 1-888-ASK-USGS.

For an overview of USGS information products, including maps, imagery, and publications, visit https://store.usgs.gov.

Any use of trade, firm, or product names is for descriptive purposes only and does not imply endorsement by the U.S. Government.

Although this information product, for the most part, is in the public domain, it also may contain copyrighted materials as noted in the text. Permission to reproduce copyrighted items must be secured from the copyright owner.

Suggested citation:

Beman, J.E., and Bryant, C.F., 2016, Water-level data for the Albuquerque Basin and adjacent areas, central New Mexico, period of record through September 30, 2015 (ver. 1.1, August 2021): U.S. Geological Survey Data Series 1025, 39 p., https://doi.org/10.3133/ds1025.

ISSN 2327-638X (online) 


\section{Contents}

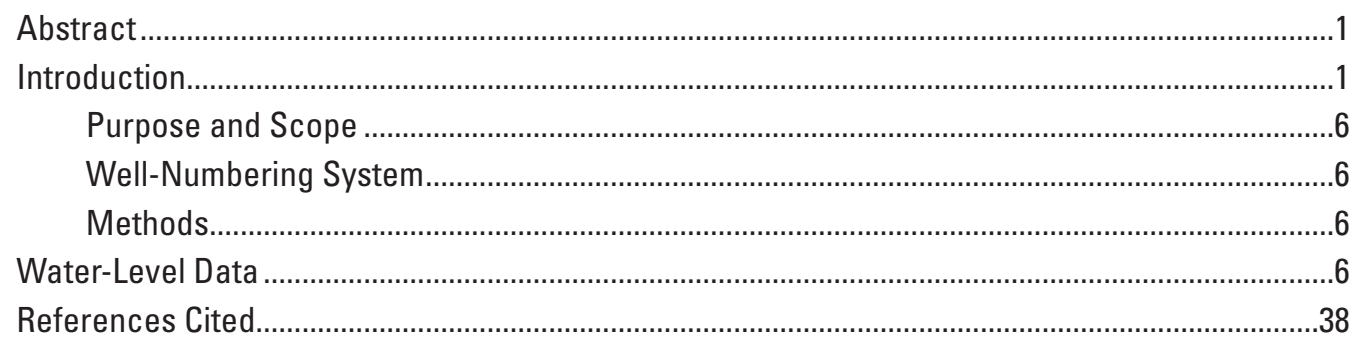

\section{Figures}

1. Map showing location of the study area and selected monitoring wells and piezometers in and adjacent to the Albuquerque Basin,

2. Map showing location of selected monitoring wells and piezometers within the Albuquerque, New Mexico, metropolitan area

3. Diagram showing system for numbering wells and piezometers in New Mexico.

4. Graphs showing water-level data for selected wells and piezometers in the Albuquerque Basin, central New Mexico, period of record through September 30, 2015.

\section{Tables}

1. Data from selected wells and piezometers in and adjacent to the Albuquerque Basin, central New Mexico, period of record through September 30, 2015

\section{Conversion Factors}

U.S. customary units to International System of Units

\begin{tabular}{|c|c|c|}
\hline Multiply & By & To obtain \\
\hline \multicolumn{3}{|c|}{ Length } \\
\hline foot $(\mathrm{ft})$ & 0.3048 & meter $(\mathrm{m})$ \\
\hline mile (mi) & 1.609 & kilometer $(\mathrm{km})$ \\
\hline \multicolumn{3}{|c|}{ Area } \\
\hline acre & 4,047 & square meter $\left(\mathrm{m}^{2}\right)$ \\
\hline
\end{tabular}




\section{Datum}

Vertical coordinate information is referenced to the National Geodetic Vertical Datum of 1929 (NGVD 29).

\section{Supplemental Information}

Water year is defined as beginning 0 ctober 1 and continuing through September 30 of the following year. 


\title{
Water-Level Data for the Albuquerque Basin and Adjacent Areas, Central New Mexico, Period of Record Through September 30, 2015
}

\author{
By Joseph E. Beman and Christina F. Bryant
}

\begin{abstract}
The Albuquerque Basin, located in central New Mexico, is about 100 miles long and 25-40 miles wide. The basin is hydrologically defined as the extent of consolidated and unconsolidated deposits of Tertiary and Quaternary age that encompasses the structural Rio Grande Rift between San Acacia to the south and Cochiti Lake to the north. Drinkingwater supplies throughout the basin were obtained solely from groundwater resources until December 2008, when the Albuquerque Bernalillo County Water Utility Authority (ABCWUA) began treatment and distribution of surface water from the Rio Grande through the San Juan-Chama Drinking Water Project. A 20-percent population increase in the basin from 1990 to 2000 and a 22-percent population increase from 2000 to 2010 may have resulted in an increased demand for water in areas within the basin.

An initial network of wells was established by the U.S. Geological Survey (USGS) in cooperation with the City of Albuquerque from April 1982 through September 1983 to monitor changes in groundwater levels throughout the Albuquerque Basin. In 1983, this network consisted of 6 wells with analog-to-digital recorders and 27 wells where water levels were measured monthly. The network currently (2015) consists of 124 wells and piezometers. (A piezometer is a specialized well open to a specific depth in the aquifer, often of small diameter and nested with other piezometers open to different depths.) The USGS, in cooperation with the ABCWUA, currently (2015) measures and reports water levels from the 124 wells and piezometers in the network; this report presents water-level data collected by USGS personnel at those 124 sites through water year 2015 (October 1, 2014, through September 30, 2015).
\end{abstract}

\section{Introduction}

The Albuquerque Basin, located in central New Mexico, is about 100 miles long and 25-40 miles wide (fig. 1). The basin is defined as the extent of consolidated and unconsolidated deposits of Tertiary and Quaternary age that encompasses the structural Rio Grande Rift within the basin
(Thorn and others, 1993). The basin is approximately bisected by the southward-flowing Rio Grande, the only perennial stream extending through the length of it. The study area, which includes the Albuquerque Basin and adjacent areas, extends from just upstream of Cochiti Lake south to San Acacia and from Tijeras Canyon west to near the intersection of Interstate 40 and the Bernalillo-Cibola County line.

In 2000, the population of the Albuquerque Basin was about 690,000 (Bartolino and Cole, 2002). According to 2010 U.S. Census Bureau data, the 2010 population was about 840,000 (U.S. Census Bureau, 2011a; calculated as sum of population for census tract centers within the basin). The majority of the population is concentrated within the city limits of Albuquerque, which had a population of 448,600 in 2000 (U.S. Census Bureau, 2001) and 545,852 in 2010 (U.S. Census Bureau, 2011b). The basin population increased about 20 percent from 1990 to 2000 (Thorn and others, 1993; Bartolino and Cole, 2002) and about 22 percent from 2000 to 2010 (U.S. Census Bureau, 2011a). Prior to 2008, demand for groundwater may have increased as population increased because drinking-water supplies throughout the Albuquerque Basin were obtained solely from groundwater sources. In December 2008, the Albuquerque Bernalillo County Water Utility Authority (ABCWUA) began treatment and distribution of surface water from the Rio Grande to their customers through the San Juan-Chama Drinking Water Project.

An initial network of wells was established by the U.S. Geological Survey (USGS) in cooperation with the City of Albuquerque from April 1982 through September 1983 to monitor changes in groundwater levels throughout the Albuquerque Basin. In 1983, this network consisted of 6 wells with analog-to-digital recorders and 27 wells where water levels were measured monthly. Since the initial installation, additional wells and piezometers have been added to the network, and currently (2015), the network consists of 124 wells and piezometers (table 1). (A piezometer is a specialized well open to a specific depth in the aquifer, often of small diameter and nested with other piezometers open to different depths.) Of these wells and piezometers, 69 are equipped with continuously recording data loggers, and 55 are measured with a steel or electric tape semiannually, quarterly, or irregularly. 


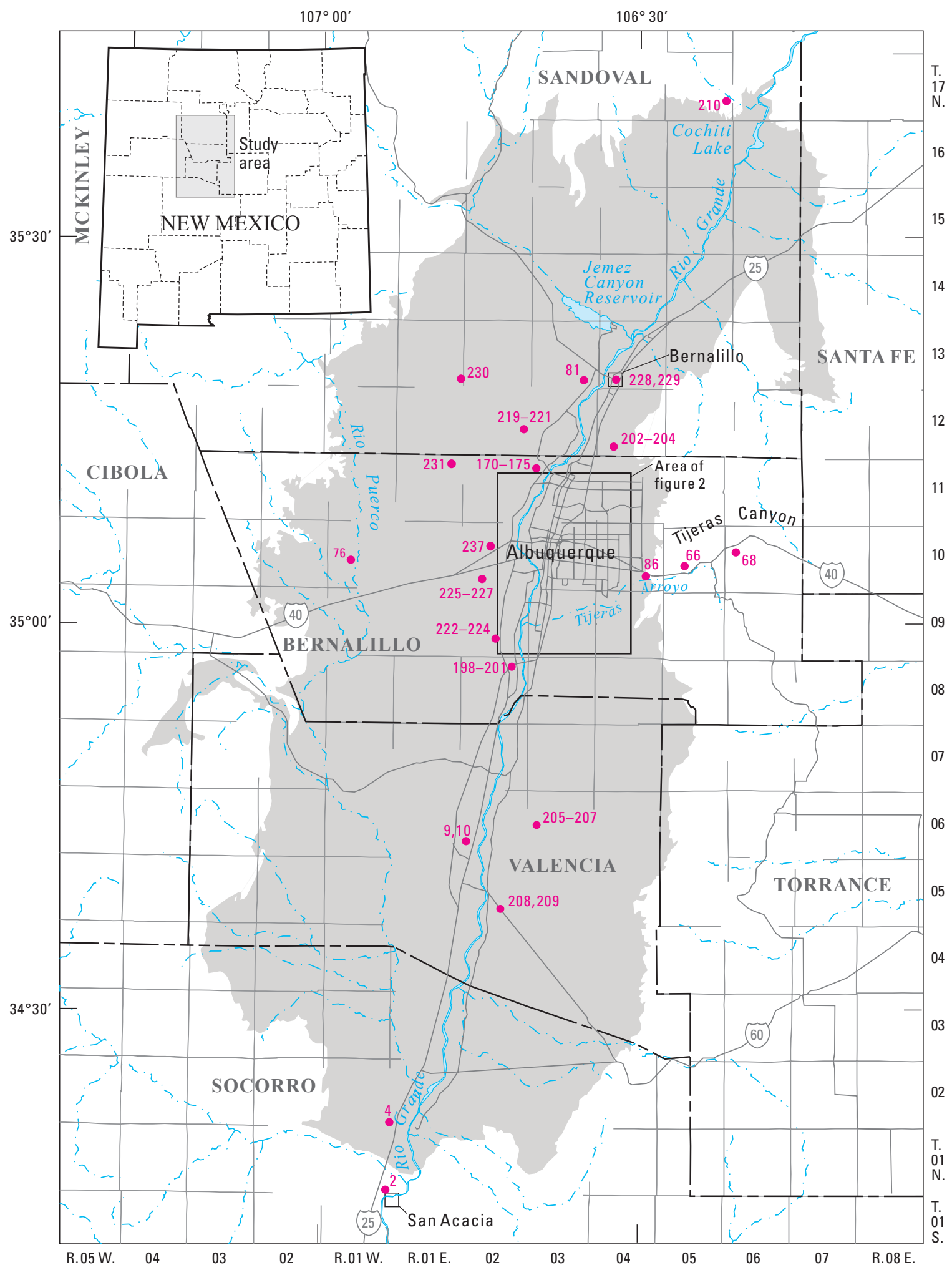

EXPLANATION

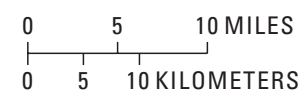

Extent of the Albuquerque Basin

-2 Monitoring well or piezometer-

Number refers to site number in

figure 4 and table 1

Figure 1. Location of the study area and selected monitoring wells and piezometers in and adjacent to the Albuquerque Basin, central New Mexico. 
Table 1. Data from selected wells and piezometers in and adjacent to the Albuquerque Basin, central New Mexico, period of record through September 30, 2015.

[USGS, U.S. Geological Survey; --, no data or not applicable. Discontinuity in numbering sequence is due to wells omitted from this report because of lack of recent data collection. Data from discontinued wells can be seen in previous USGS open-file reports and data series (Kues, 1987; Rankin, 1994, 1996, 1998, 1999, 2000; DeWees, 2001, 2002, 2003, 2006; Beman, 2007, 2008, 2009, 2011, 2012, 2013, 2014, 2015; Beman and Torres, 2010)]

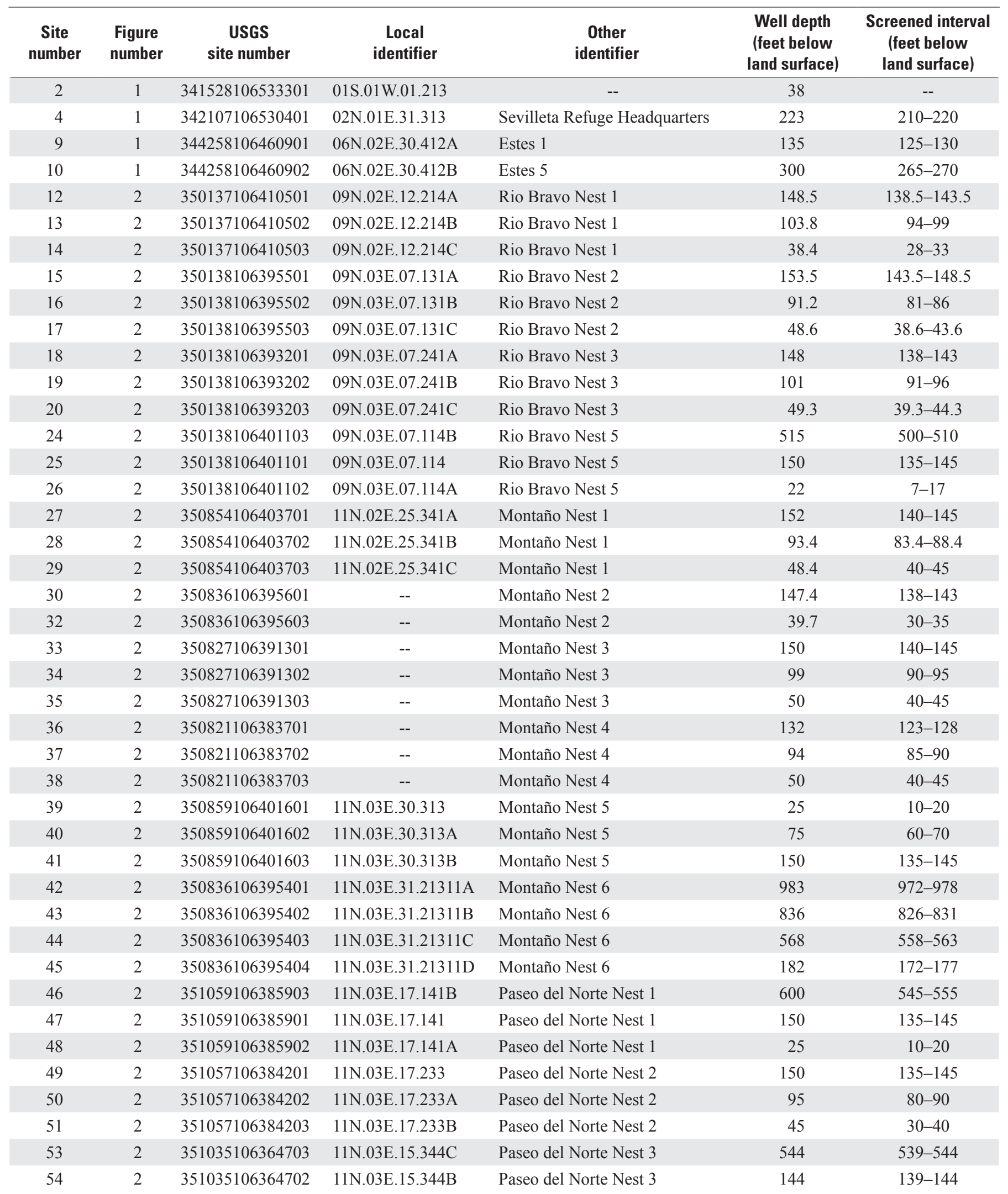


Table 1. Data from selected wells and piezometers in and adjacent to the Albuquerque Basin, central New Mexico, period of record through September 30, 2015. - Continued

[USGS, U.S. Geological Survey; --, no data or not applicable. Discontinuity in numbering sequence is due to wells omitted from this report because of lack of recent data collection. Data from discontinued wells can be seen in previous USGS open-file reports and data series (Kues, 1987; Rankin, 1994, 1996, 1998, 1999, 2000; DeWees, 2001, 2002, 2003, 2006; Beman, 2007, 2008, 2009, 2011, 2012, 2013, 2014, 2015; Beman and Torres, 2010)]

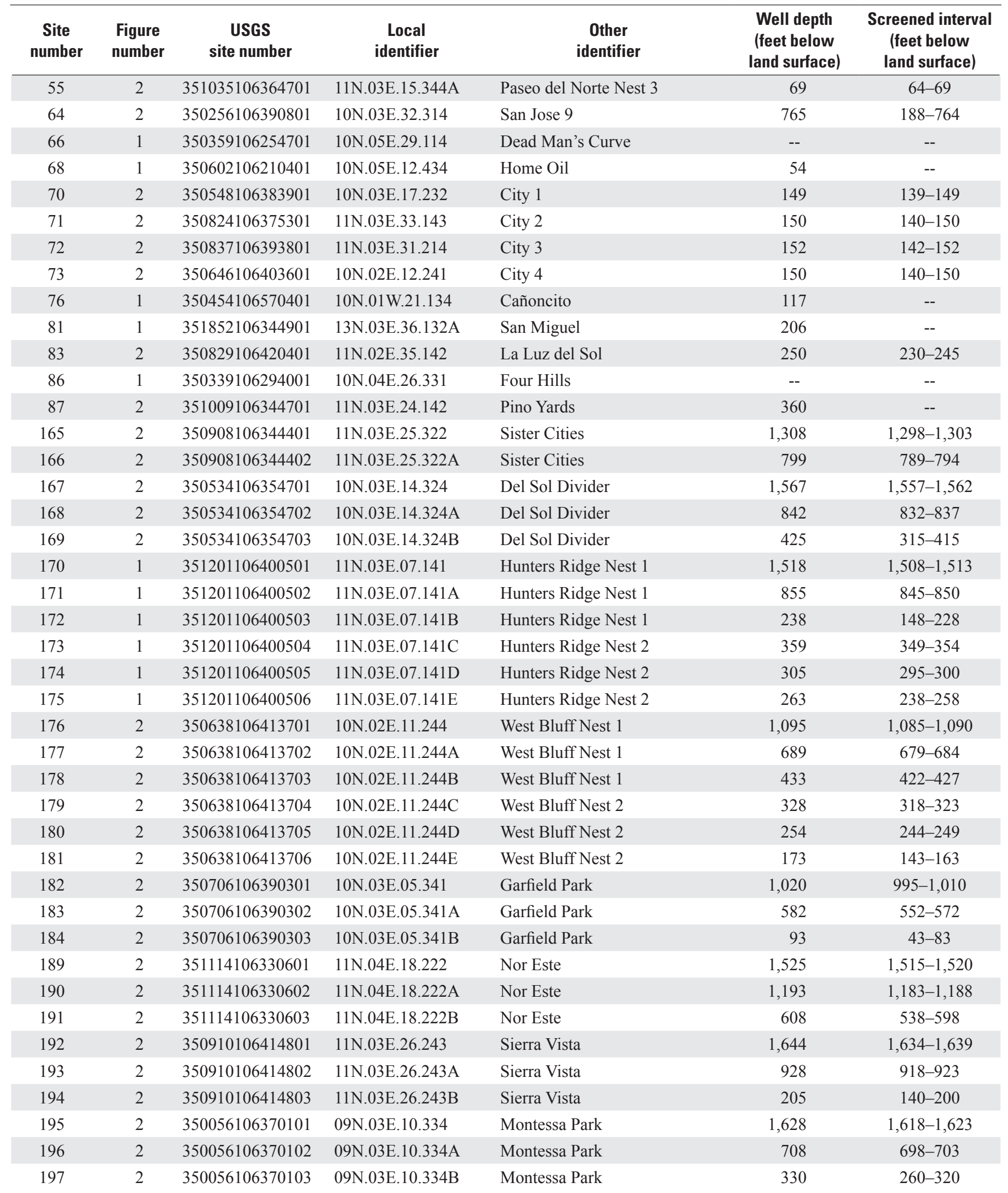


Table 1. Data from selected wells and piezometers in and adjacent to the Albuquerque Basin, central New Mexico, period of record through September 30, 2015.-Continued

[USGS, U.S. Geological Survey; --, no data or not applicable. Discontinuity in numbering sequence is due to wells omitted from this report because of lack of recent data collection. Data from discontinued wells can be seen in previous USGS open-file reports and data series (Kues, 1987; Rankin, 1994, 1996, 1998, 1999, 2000; DeWees, 2001, 2002, 2003, 2006; Beman, 2007, 2008, 2009, 2011, 2012, 2013, 2014, 2015; Beman and Torres, 2010)]

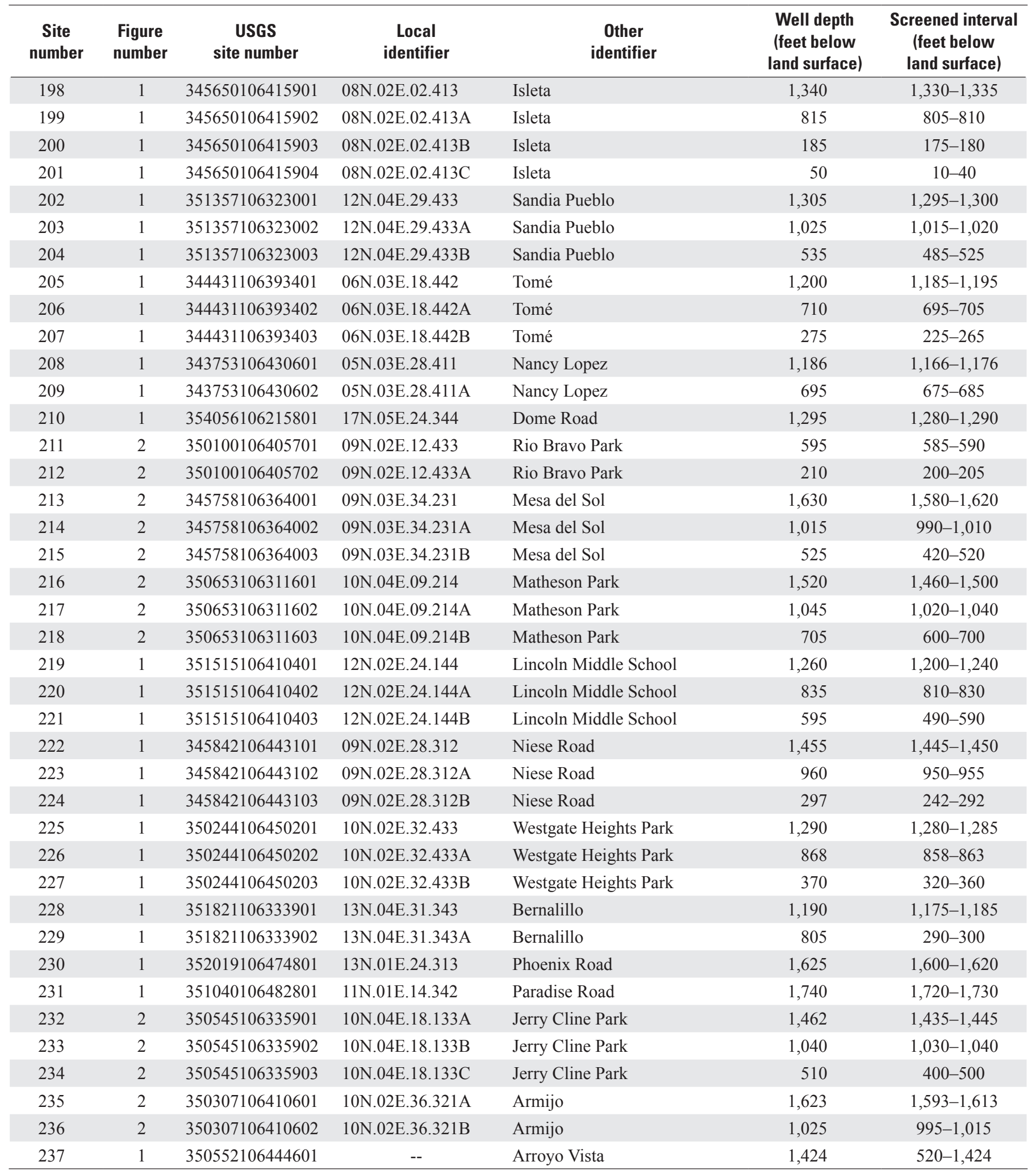


The USGS, in cooperation with the ABCWUA, currently (2015) measures and reports water levels from the 124 wells and piezometers in the network (table 1). Monitoring-well locations within the basin and adjacent areas are shown in figure 1, and those within the Albuquerque metropolitan area are shown in figure 2 .

\section{Purpose and Scope}

The purpose of this report is to present an annual update of water-level data collected from the Albuquerque Basin well network during the 2015 water year (October 1, 2014, through September 30, 2015). Water-level data collected from the Albuquerque Basin and adjacent areas for the period of record through September 30, 2015, are presented. Water-level data that were collected from wells in previous water years, but not during the 2015 water year, can be found in previous versions of this report (Kues, 1987; Rankin, 1994, 1996, 1998, 1999, 2000; DeWees, 2001, 2002, 2003, 2006; Beman, 2007, 2008, 2009, 2011, 2012, 2013, 2014, 2015; Beman and Torres, 2010).

\section{Well-Numbering System}

The system of numbering wells and piezometers in New Mexico is based on the common subdivision of public lands into sections (fig. 3). Each well number, in addition to designating the well, locates the position to the nearest 10 -acre tract in the land network. This number (referred to as "local identifier" in table 1) is divided into four segments. The first segment denotes the township ("T.") north or south of the New Mexico base line, the second denotes the range ("R.") east or west of the New Mexico principal meridian, and the third denotes the section. The fourth segment of the well number, which consists of three digits, denotes the 160-, $40-$, and 10-acre tracts in which the well is located. Each section is divided into quarters - numbered 1, 2, 3, and 4-for the northwest, northeast, southwest, and southeast quarters, respectively. The first digit of the fourth segment gives the quarter section, which is a tract of 160 acres. Each quarter section is then subdivided into four 40 -acre tracts numbered in the same manner, and the second digit denotes the 40-acre tract. Finally, each 40 -acre tract is further subdivided into four 10-acre tracts, and the third digit denotes the 10-acre tract. The fourth segment of the well number can further denote subdivisions of the 10 -acre tract by including more than three digits; each additional digit further subdivides the tract by quarters in the same manner as shown in figure 3. Letters A, B, C, and so on are added to the end of the last segment of the well number to designate the second, third, fourth, and succeeding wells in the same tract. For example, well 09N.03E.07.131A is the first subsequent well in the northwest quarter (NW 1/4) of the southwest quarter (SW 1/4) of the northwest quarter (NW 1/4) of section 7, T. 09 N., R. 03 E. (fig. 3).

\section{Methods}

Water-level measurements at all wells and piezometers were collected by following standard USGS Office of Groundwater protocols for discrete and continuous groundwater measurements using electric and steel tapes (Cunningham and Schalk, 2011). Fifty of the sites $(2,4,9,10$, 12-20, 24-30, 32-41, 46-51, 53-55, 68, 70-73, 76, 81, 83, 86,87 , and 237) are measured semiannually, and two of the sites (230 and 231) are measured quarterly or irregularly. At 69 of the sites $(42-45,64,66,165-184,189-221,225-229$, and 232-236), pressure transducers and data loggers are used to collect hourly water-level data. The transducers and data loggers were removed from sites 222-224, but periodic measurements continue; the equipment may be redeployed to these piezometers after repairs are made to equipment housing.

\section{Water-Level Data}

Data for the 124 wells and piezometers in the network include site number, number of the figure on which the well location is shown, USGS site number, local identifier (if applicable), other identifier (if applicable), well depth, and screened interval (table 1). Hydrographs presenting waterlevel data collected by the USGS include water level in feet below land surface and water level in feet above the National Geodetic Vertical Datum of 1929 (NGVD 29) (fig. 4). Data in hydrographs from wells that have continuous recorders are shown by solid lines that represent continuous data (fig. 4). In hydrographs that present data from periodically measured wells, dashed lines connect symbols ("“+") that represent the periodic measurements (fig. 4). In hydrographs showing periodically measured piezometers that are nested (more than one trace per graph), the symbols were removed to make the hydrographs easier to read (fig. 4). There are two hydrographs presenting data for sites 42-45: one showing periodic waterlevel measurements and one showing continuous data (fig. 4). Data gaps are present in some of the hydrographs; these gaps may be caused by, but are not limited to, equipment malfunction or removal of spurious data.

Starting in early 2009, the water levels in the deep piezometer at the Montessa Park site (site 195; fig. 4) appear to have been affected by sediment in the well. The water levels in this piezometer probably reflect seasonal water-level changes in the aquifer but are not a reliable indicator of daily or weekly water-level changes. 


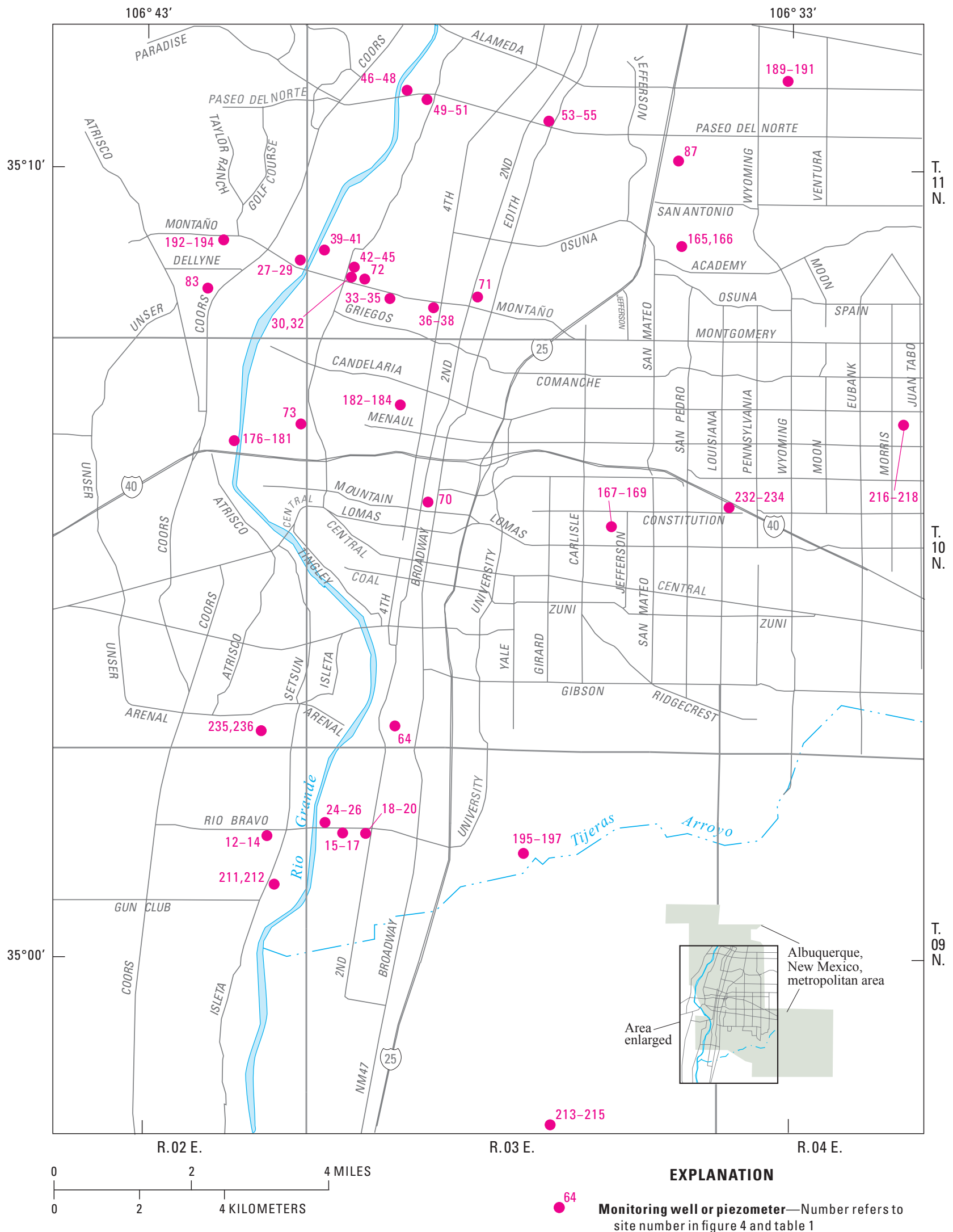

Figure 2. Location of selected monitoring wells and piezometers within the Albuquerque, New Mexico, metropolitan area. 


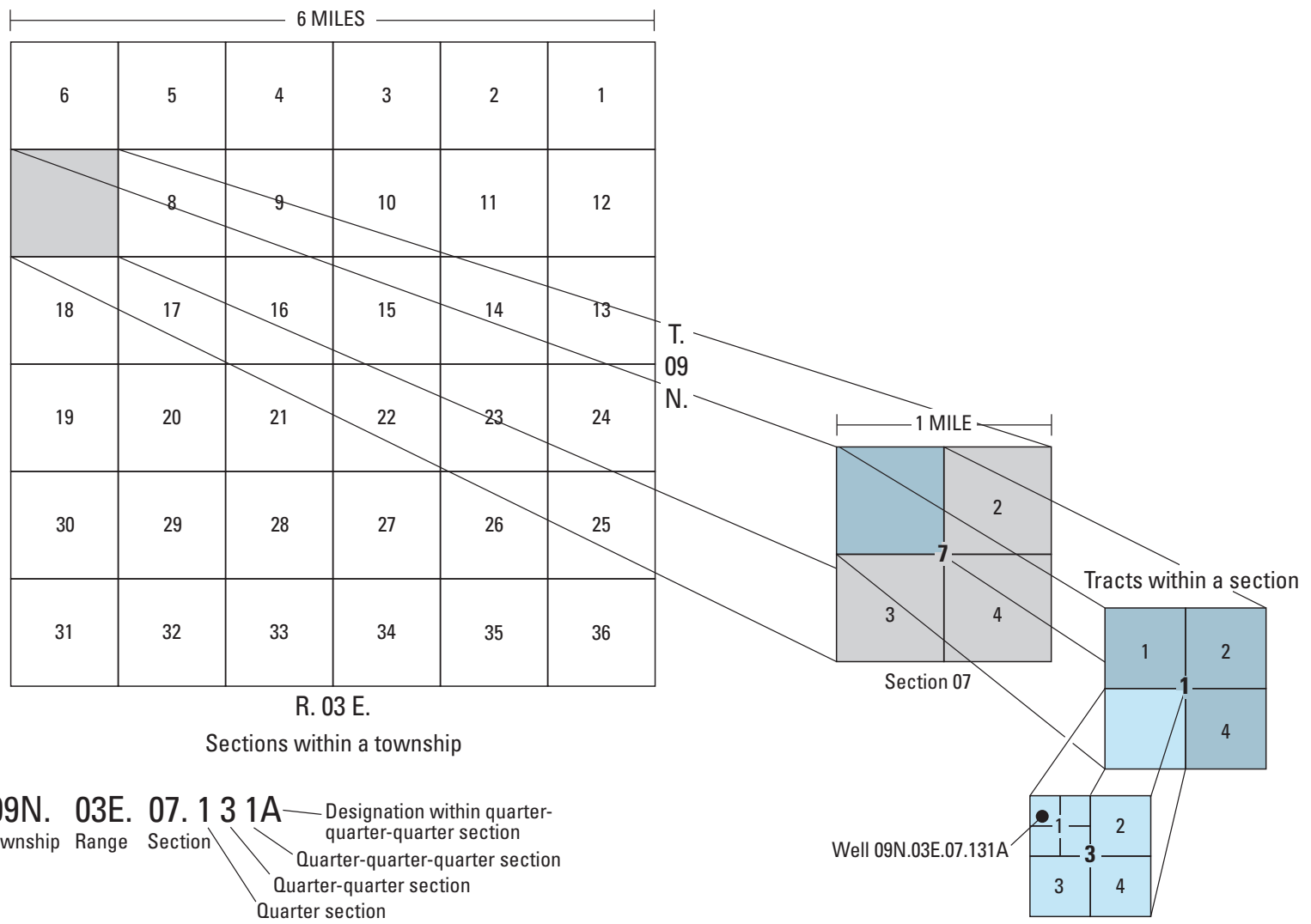

Figure 3. System for numbering wells and piezometers in New Mexico. 

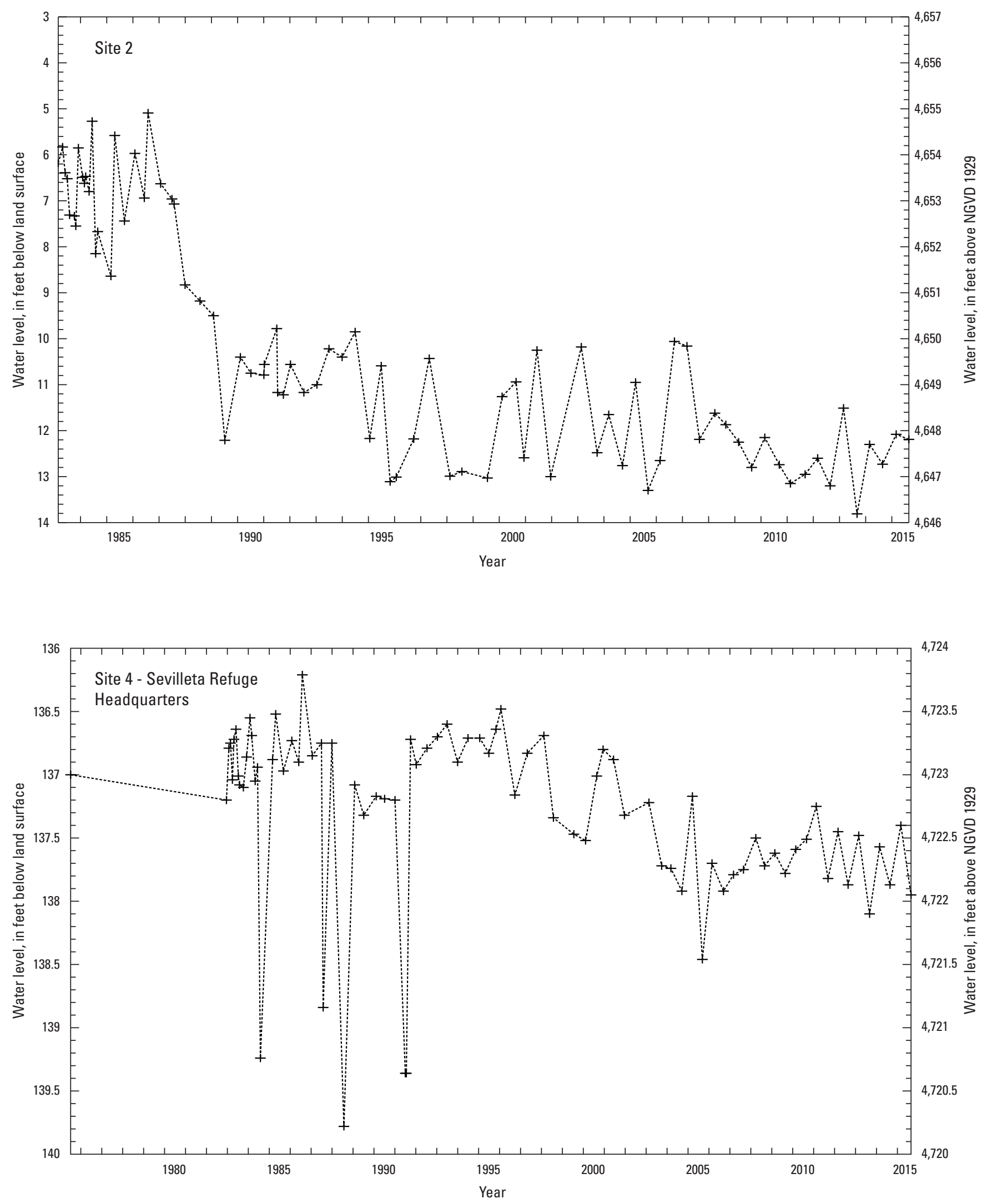

Figure 4. Water-level data for selected wells and piezometers in the Albuquerque Basin, central New Mexico, period of record through September 30, 2015 (NGVD 29, National Geodetic Vertical Datum of 1929). 

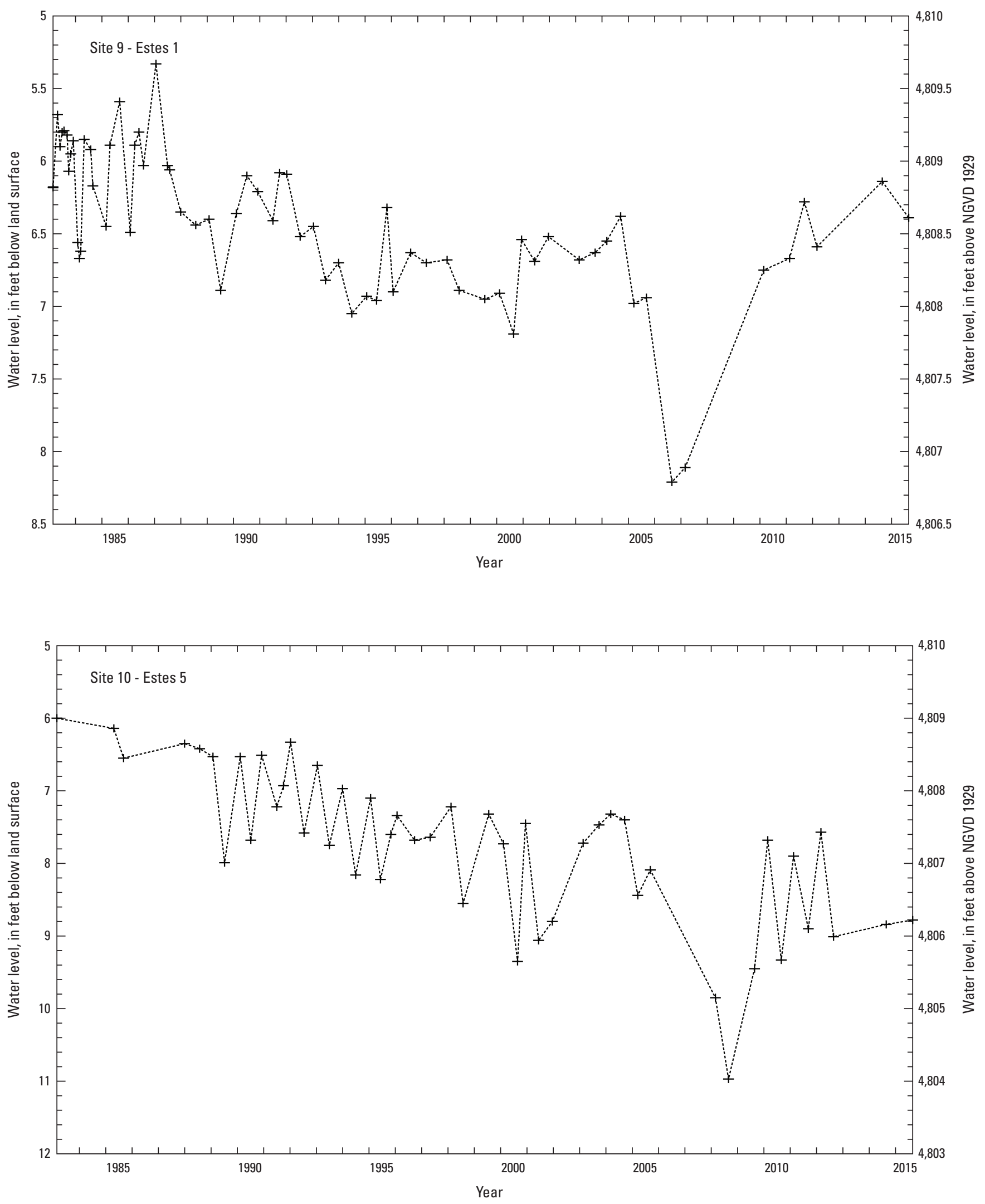

Figure 4. Water-level data for selected wells and piezometers in the Albuquerque Basin, central New Mexico, period of record through September 30, 2015 (NGVD 29, National Geodetic Vertical Datum of 1929)._Continued 

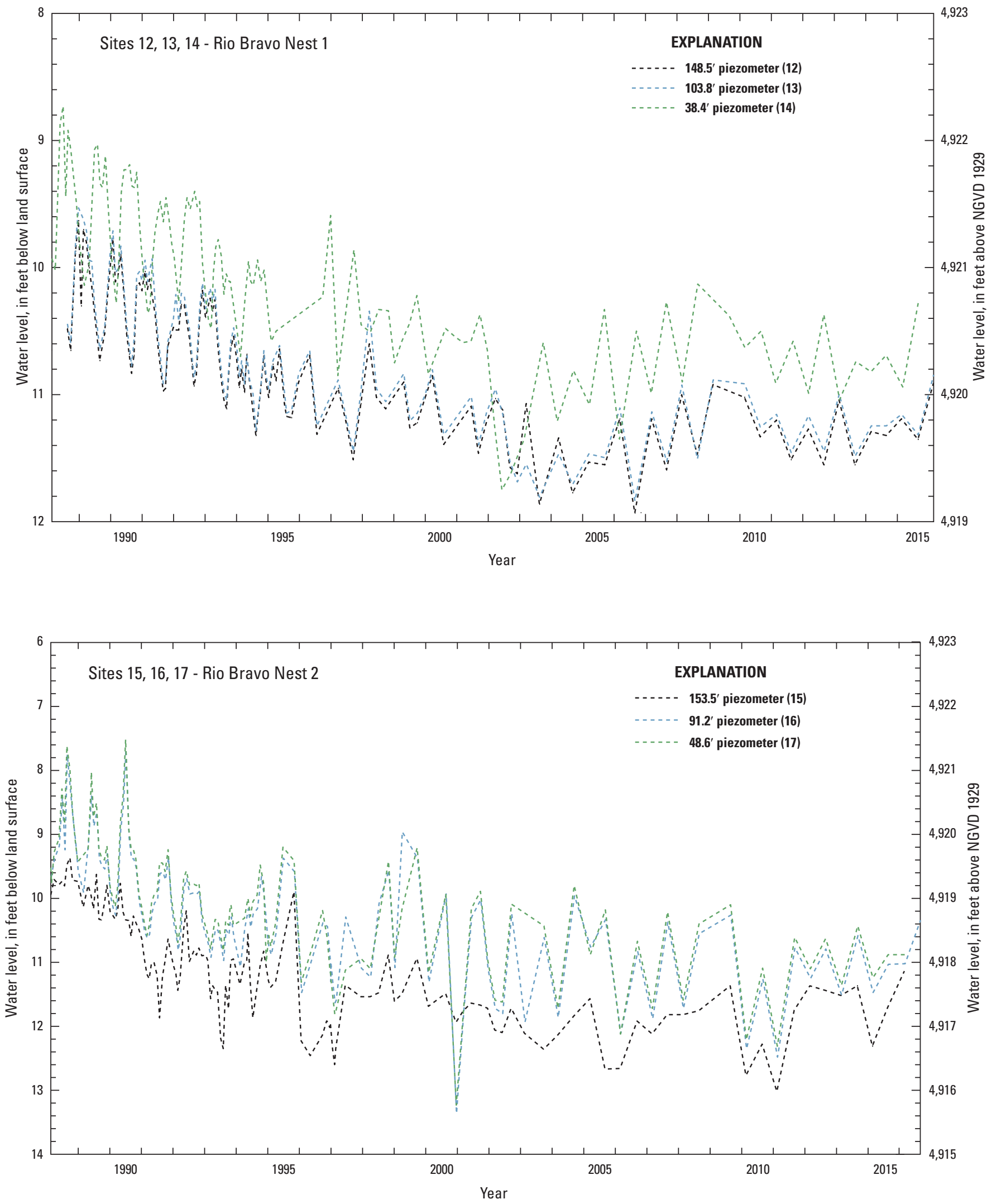

Figure 4. Water-level data for selected wells and piezometers in the Albuquerque Basin, central New Mexico, period of record through September 30, 2015 (NGVD 29, National Geodetic Vertical Datum of 1929).-Continued 

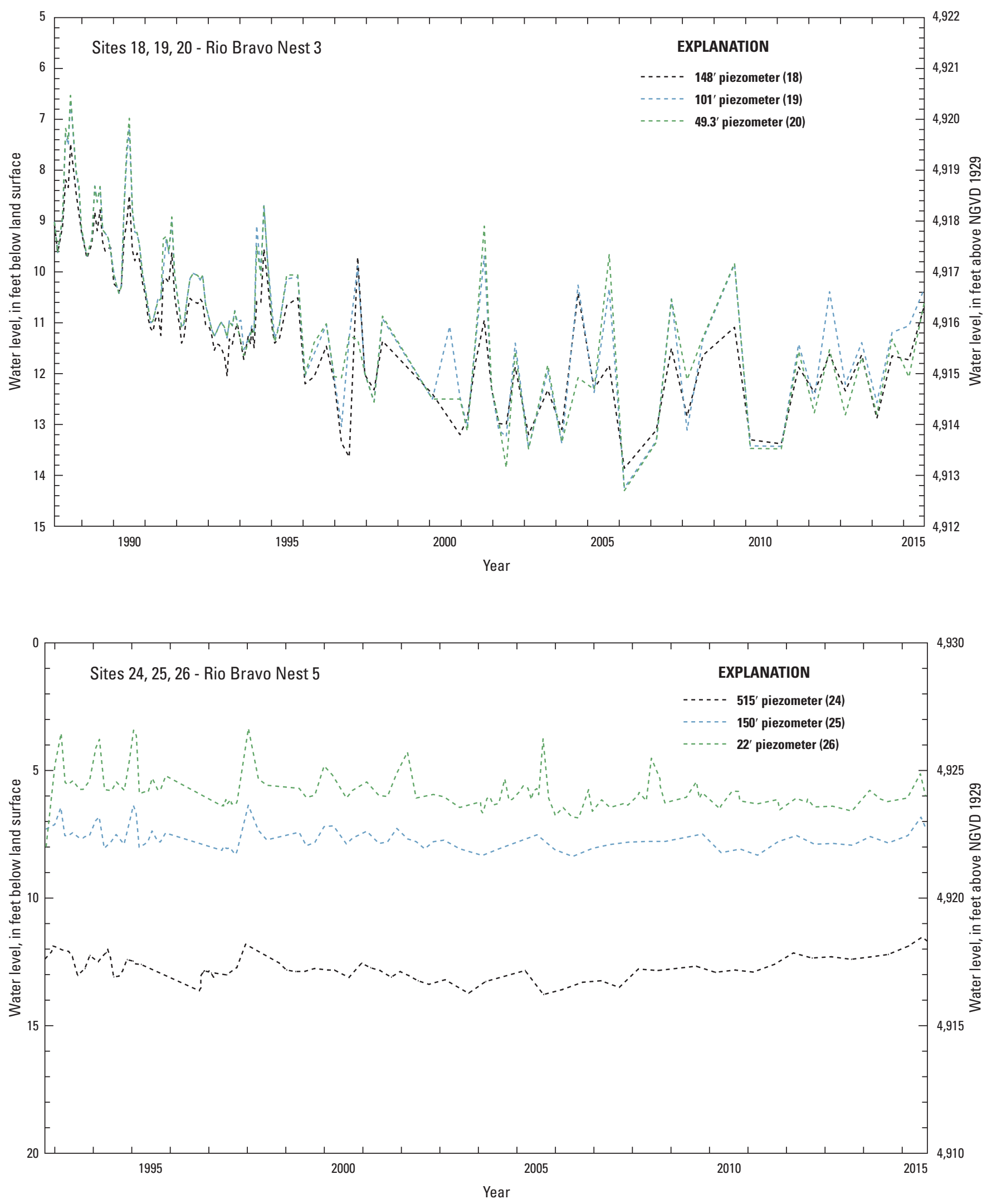

Figure 4. Water-level data for selected wells and piezometers in the Albuquerque Basin, central New Mexico, period of record through September 30, 2015 (NGVD 29, National Geodetic Vertical Datum of 1929).-Continued 

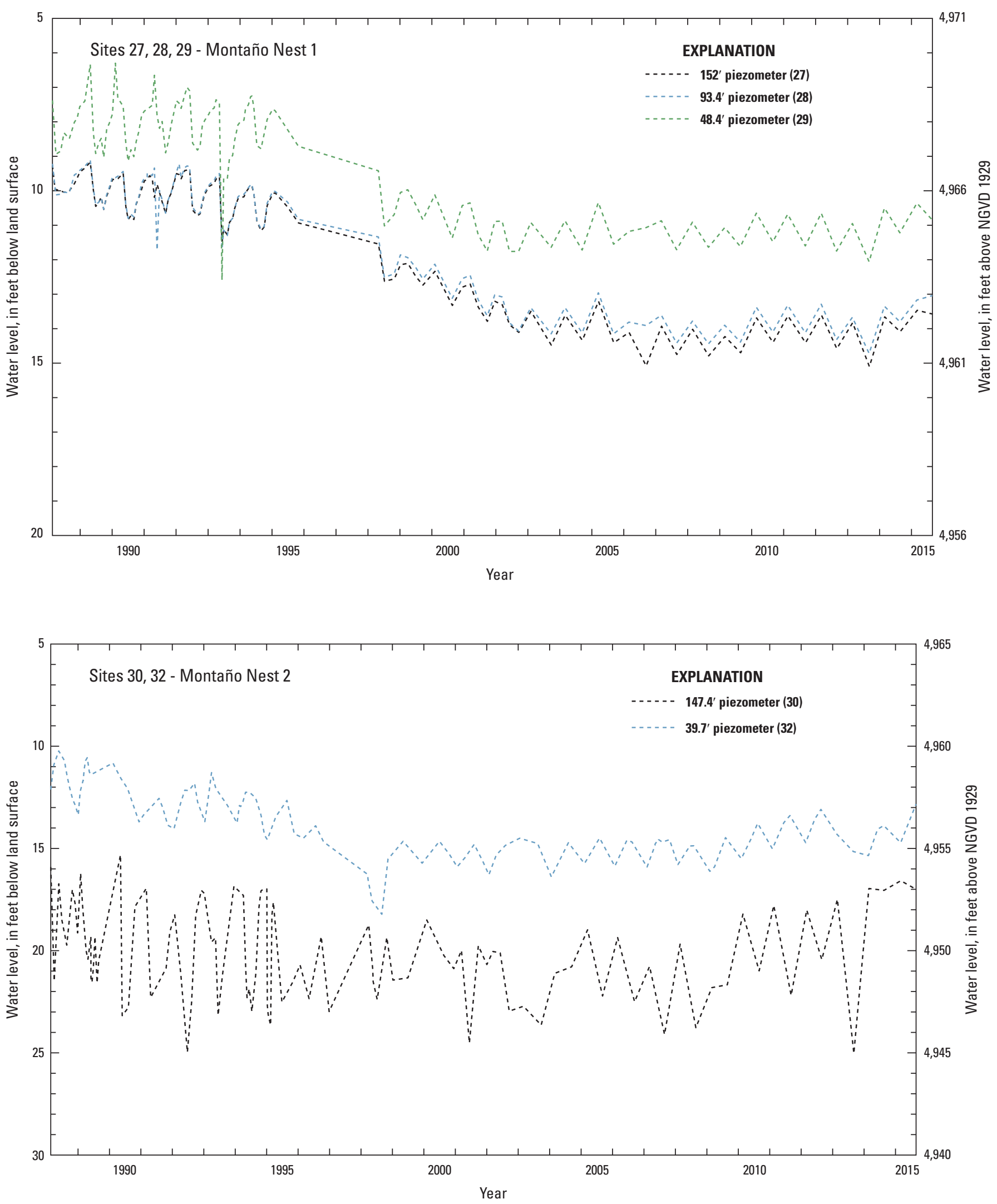

Figure 4. Water-level data for selected wells and piezometers in the Albuquerque Basin, central New Mexico, period of record through September 30, 2015 (NGVD 29, National Geodetic Vertical Datum of 1929).-Continued 

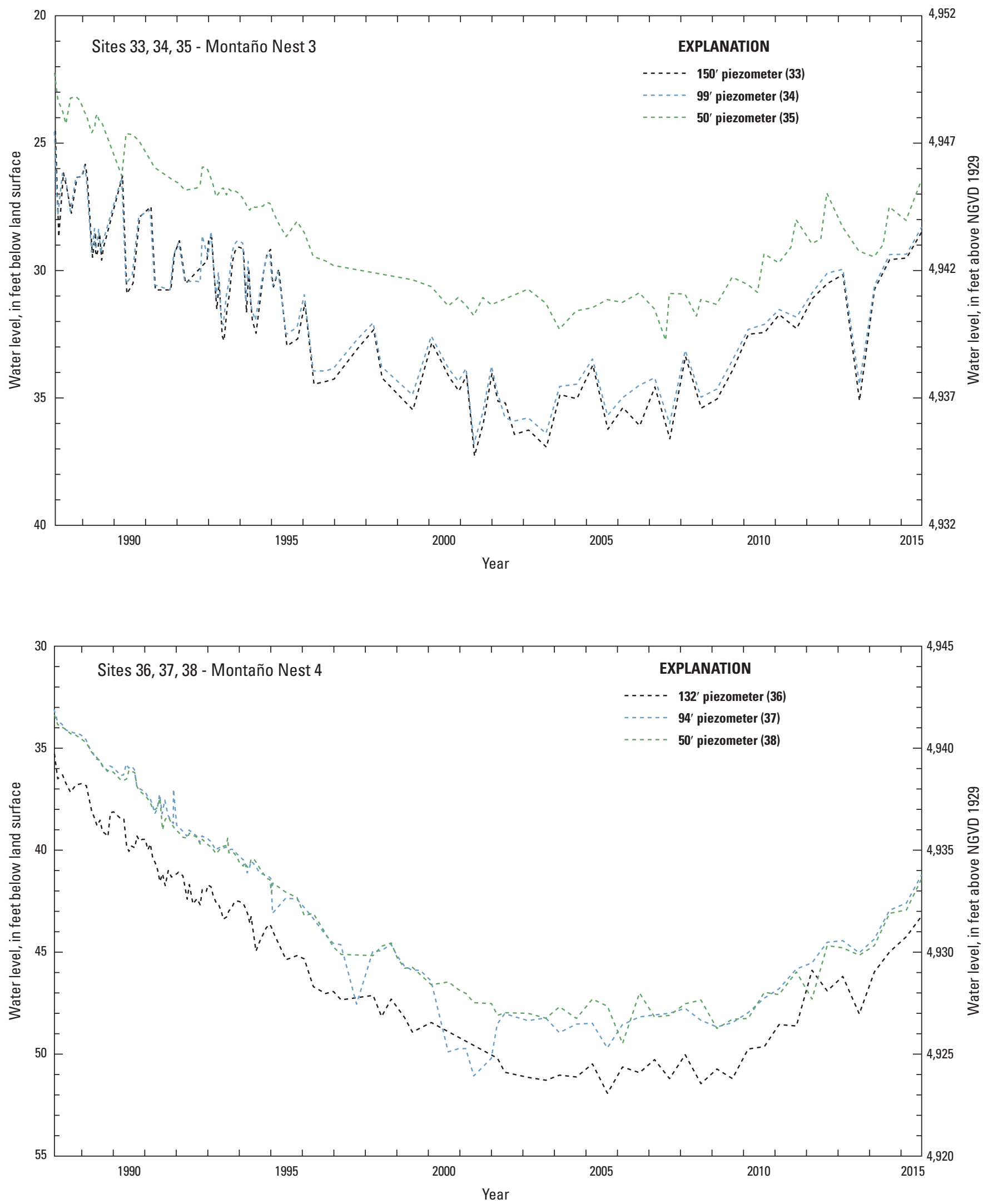

Figure 4. Water-level data for selected wells and piezometers in the Albuquerque Basin, central New Mexico, period of record through September 30, 2015 (NGVD 29, National Geodetic Vertical Datum of 1929)._Continued 

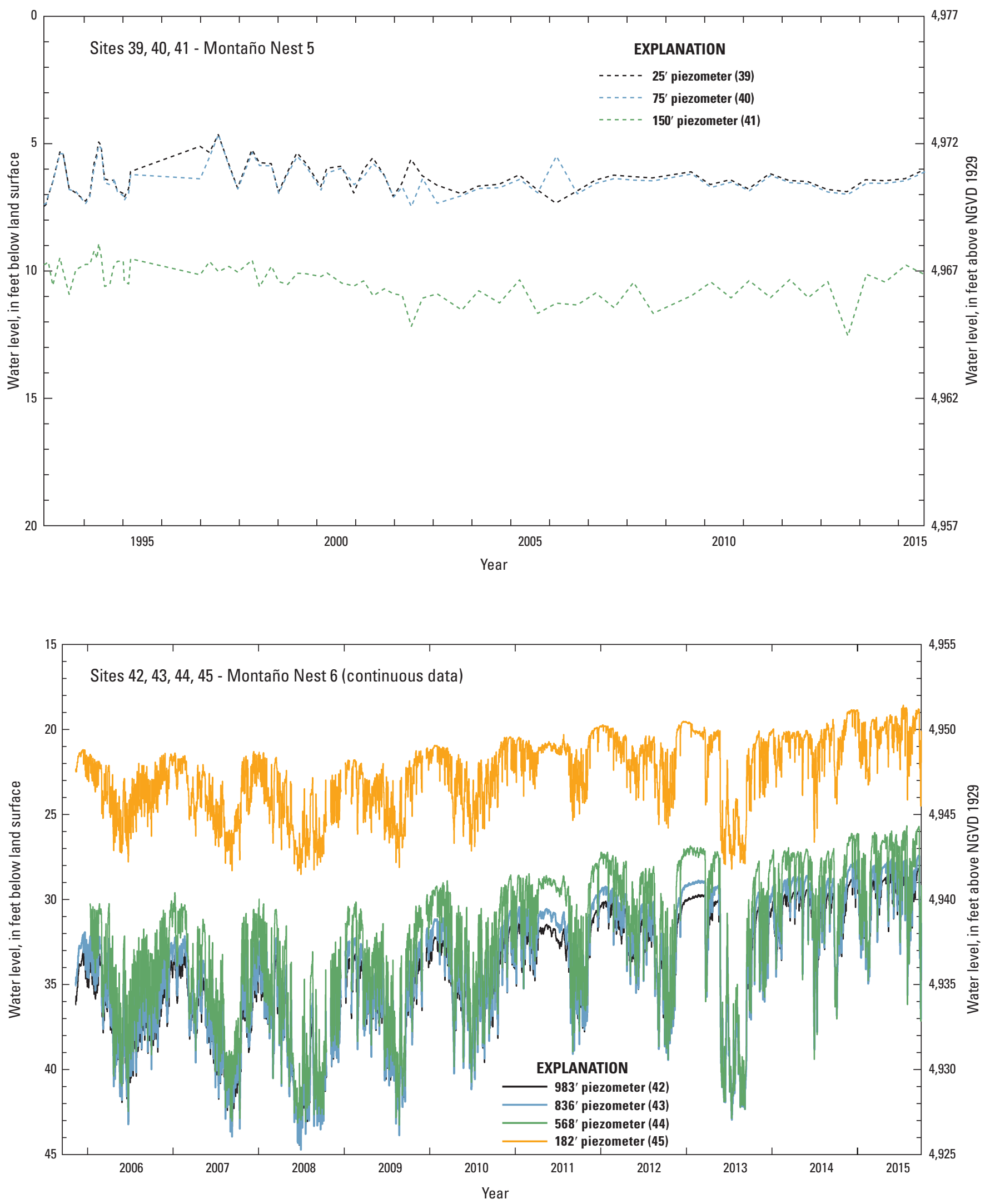

Figure 4. Water-level data for selected wells and piezometers in the Albuquerque Basin, central New Mexico, period of record through September 30, 2015 (NGVD 29, National Geodetic Vertical Datum of 1929).-Continued 

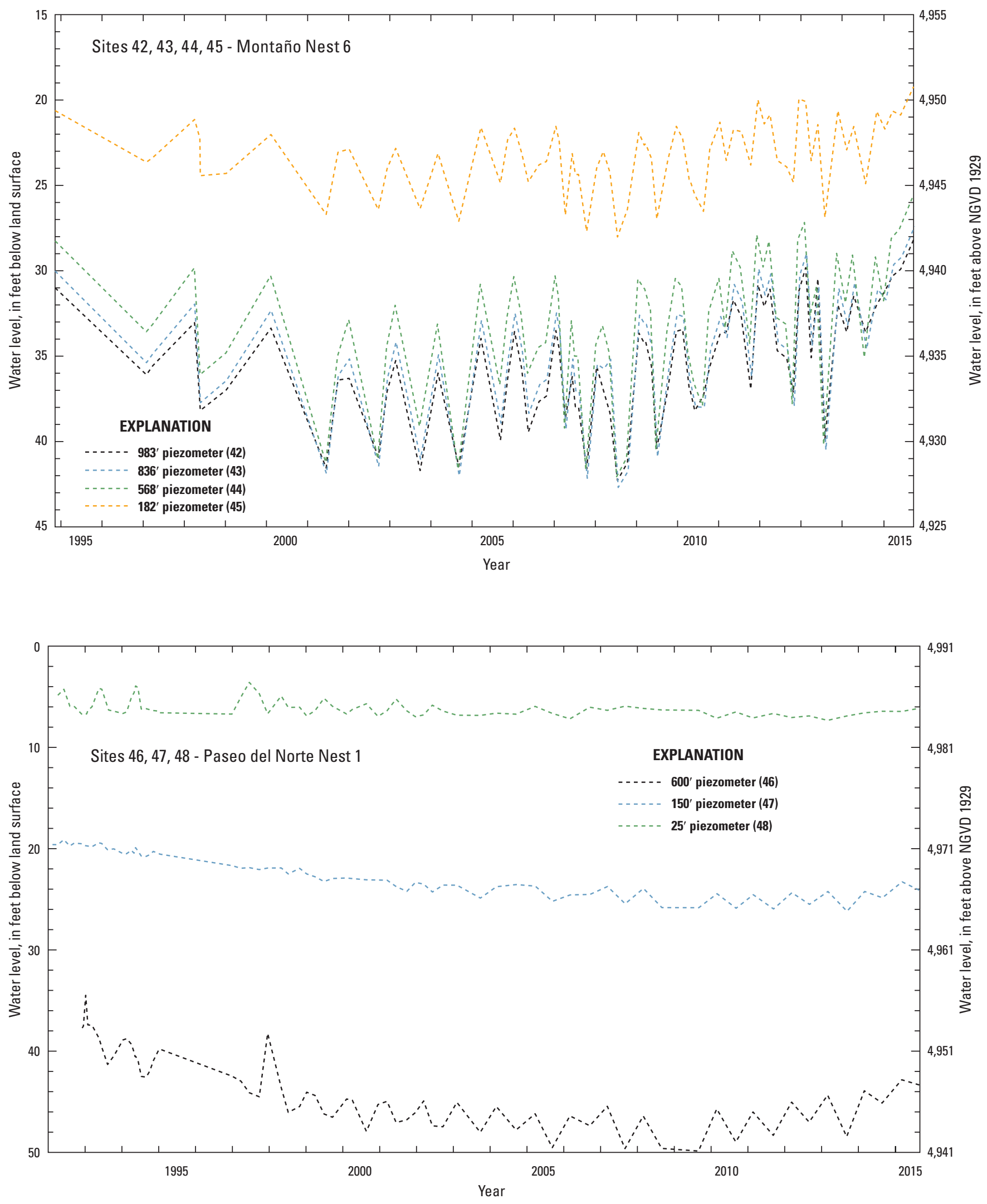

Figure 4. Water-level data for selected wells and piezometers in the Albuquerque Basin, central New Mexico, period of record through September 30, 2015 (NGVD 29, National Geodetic Vertical Datum of 1929)._Continued 

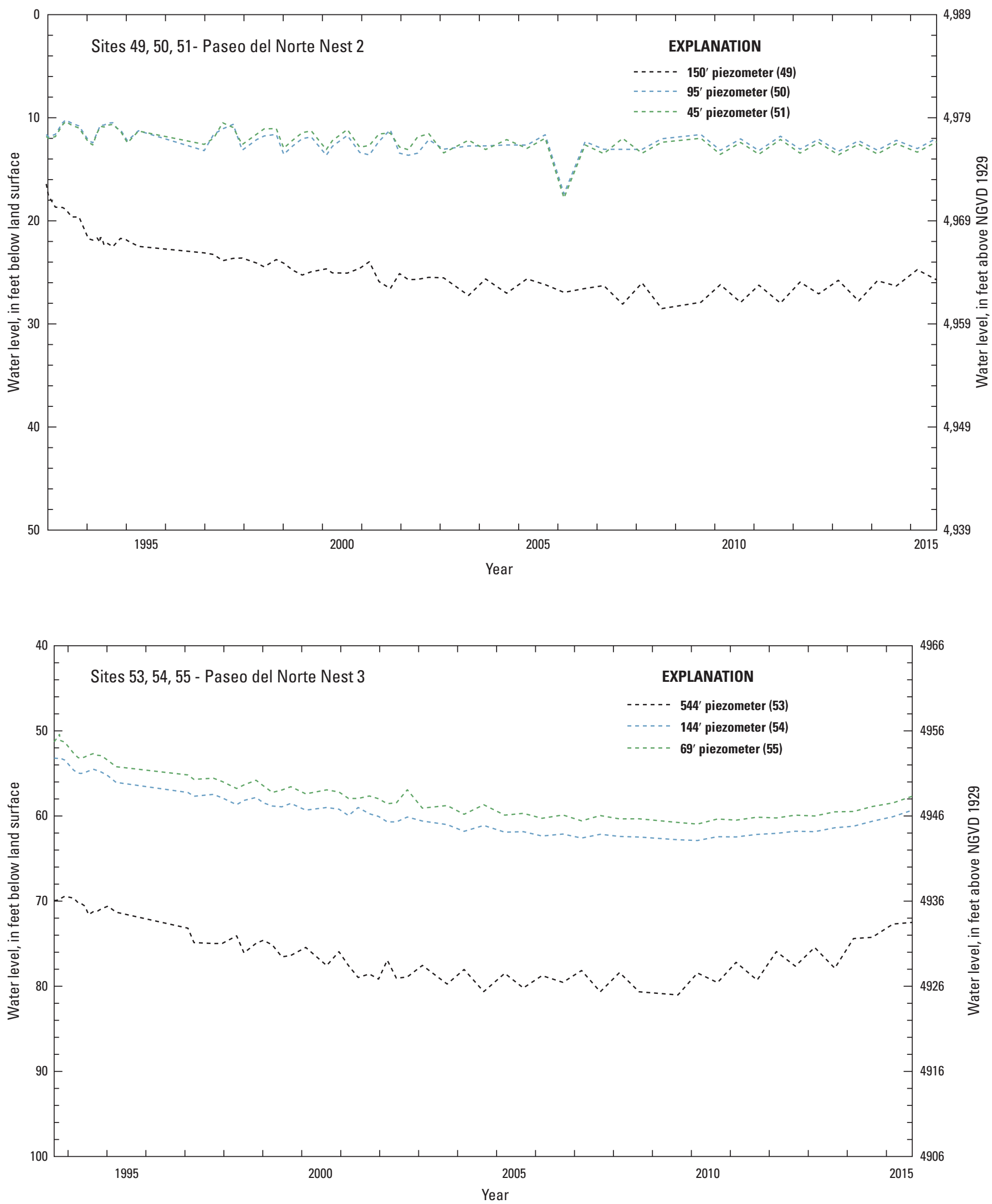

Figure 4. Water-level data for selected wells and piezometers in the Albuquerque Basin, central New Mexico, period of record through September 30, 2015 (NGVD 29, National Geodetic Vertical Datum of 1929).-Continued 

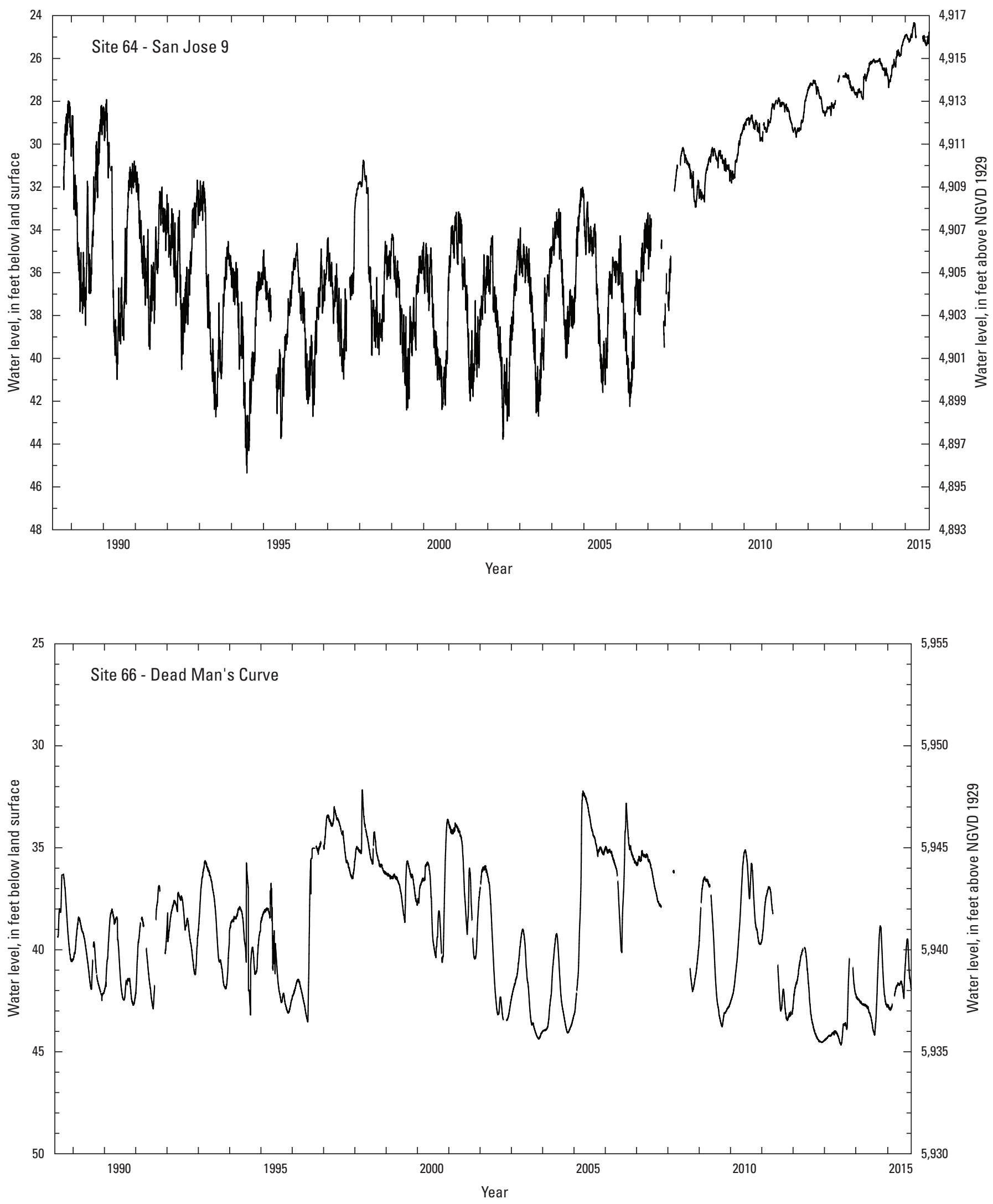

Figure 4. Water-level data for selected wells and piezometers in the Albuquerque Basin, central New Mexico, period of record through September 30, 2015 (NGVD 29, National Geodetic Vertical Datum of 1929)._Continued 

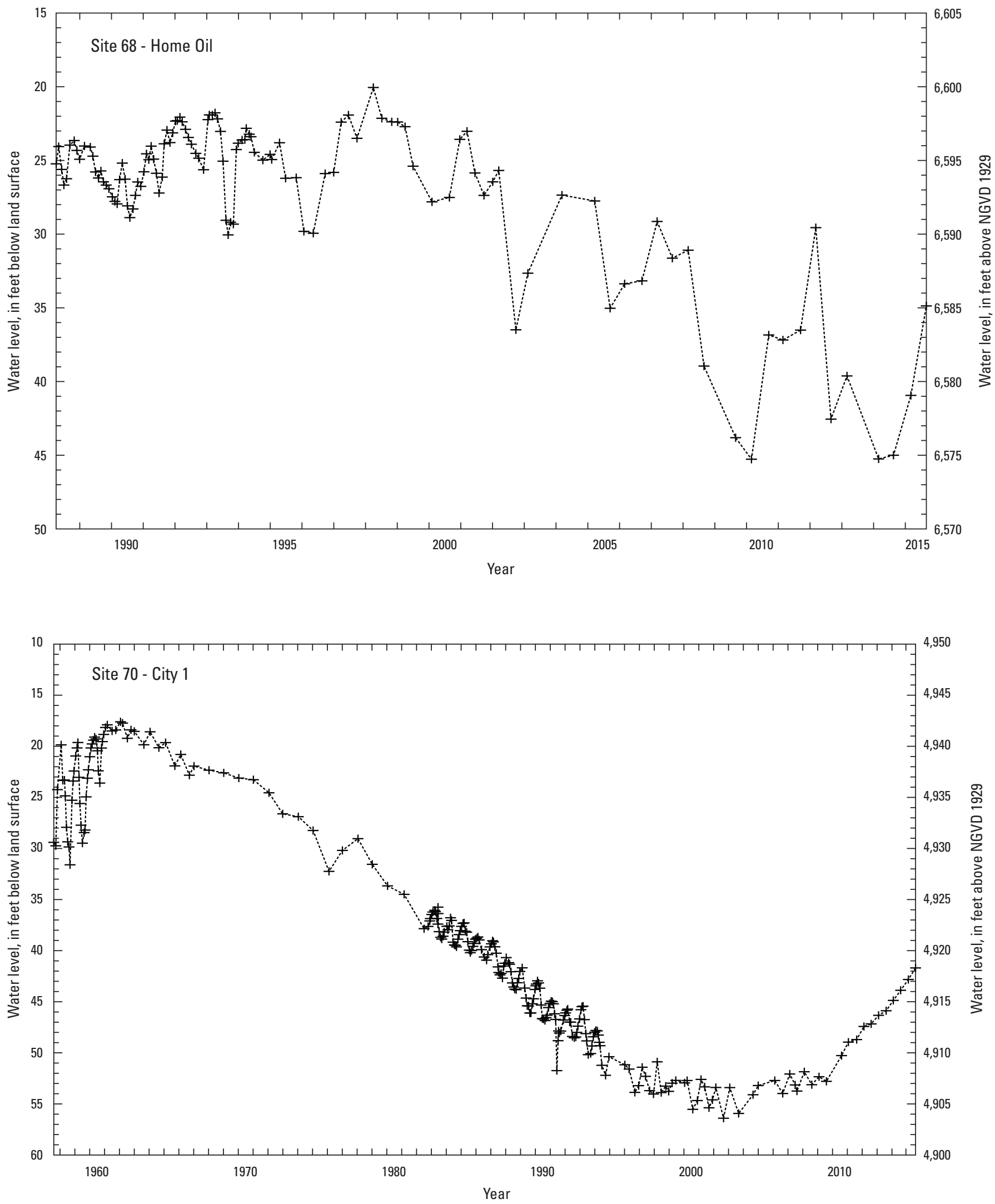

Figure 4. Water-level data for selected wells and piezometers in the Albuquerque Basin, central New Mexico, period of record through September 30, 2015 (NGVD 29, National Geodetic Vertical Datum of 1929)._-Continued 

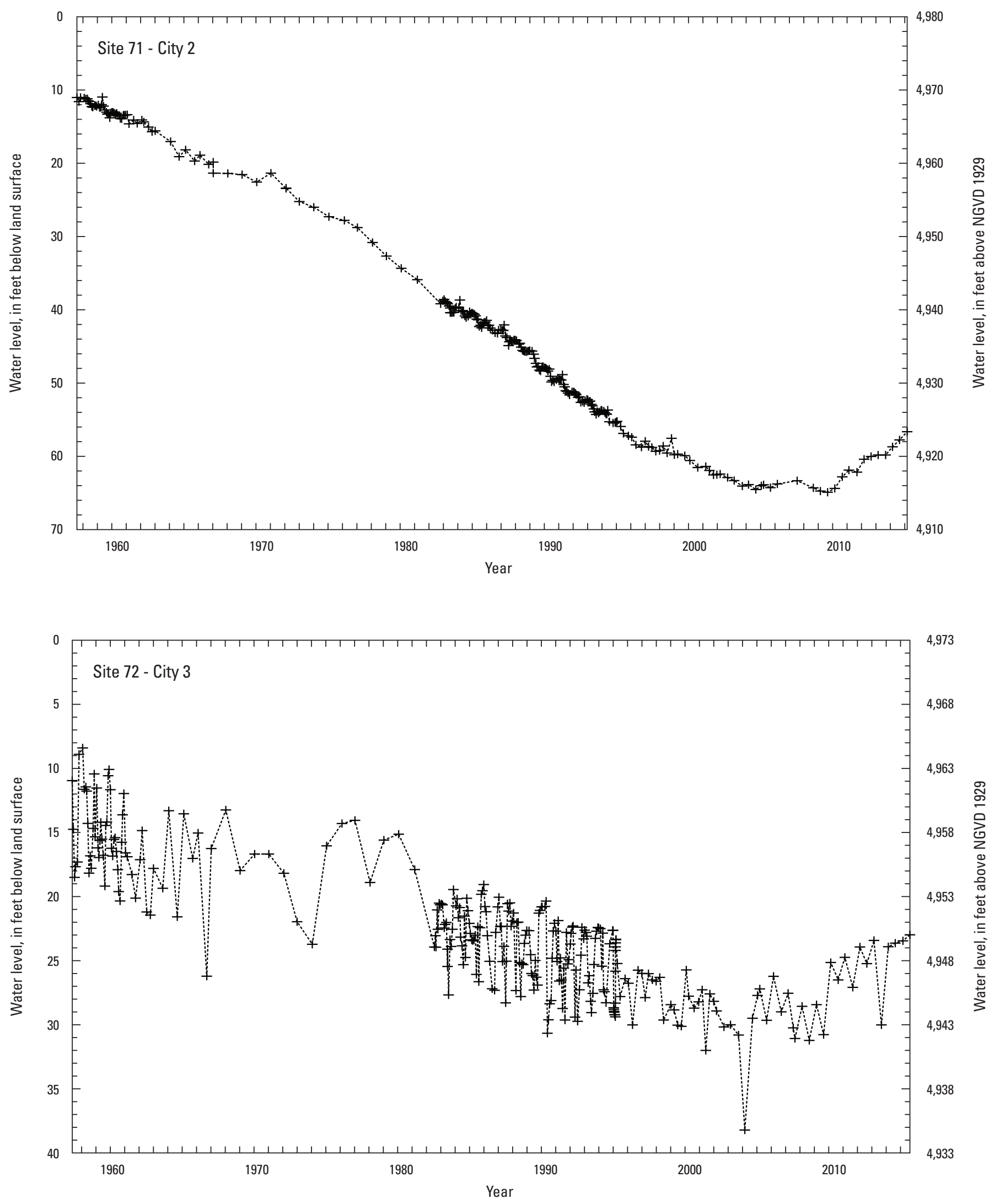

Figure 4. Water-level data for selected wells and piezometers in the Albuquerque Basin, central New Mexico, period of record through September 30, 2015 (NGVD 29, National Geodetic Vertical Datum of 1929)._Continued 

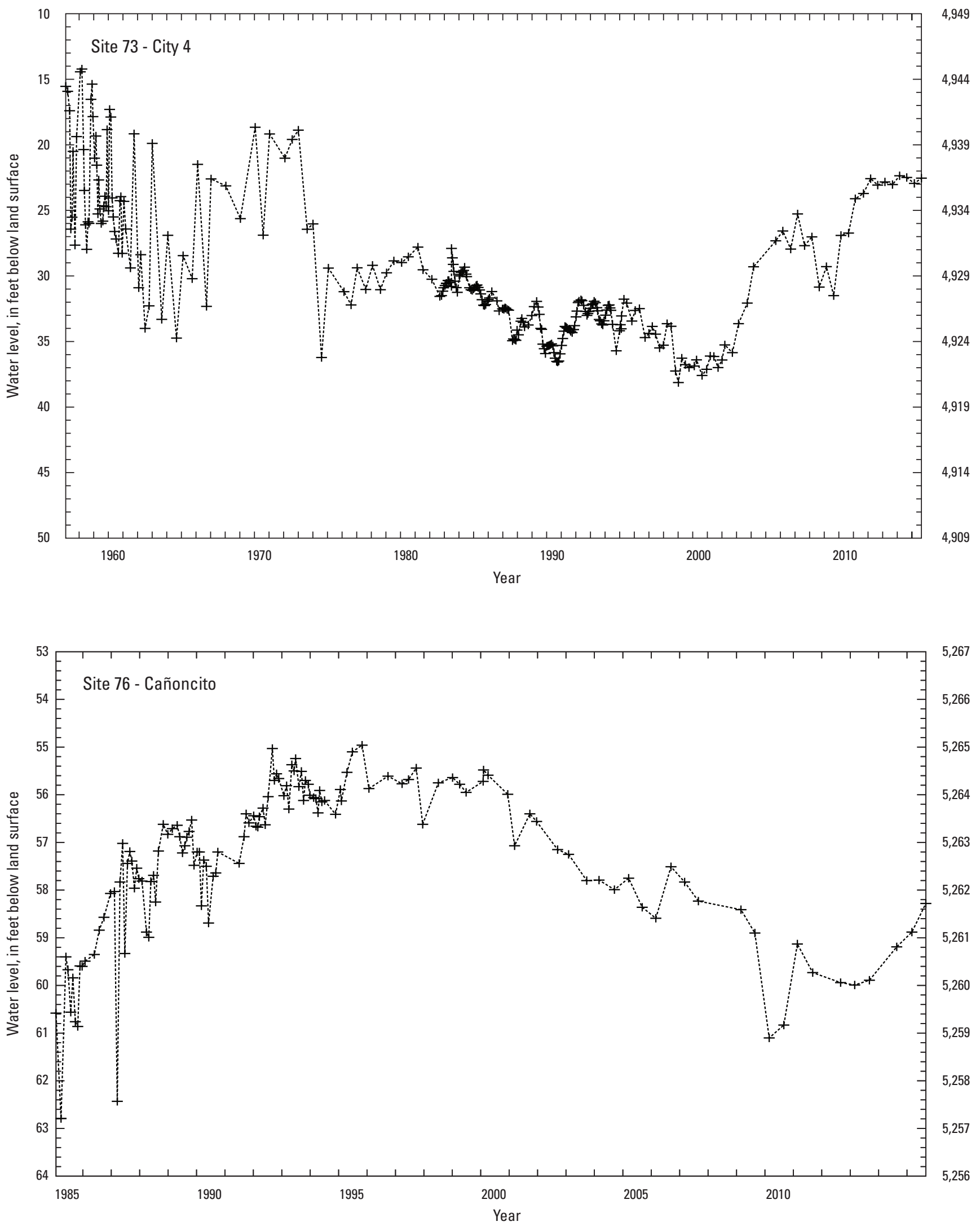

5,267

5,266

265

5,264

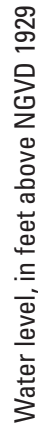

Figure 4. Water-level data for selected wells and piezometers in the Albuquerque Basin, central New Mexico, period of record through September 30, 2015 (NGVD 29, National Geodetic Vertical Datum of 1929).-Continued 

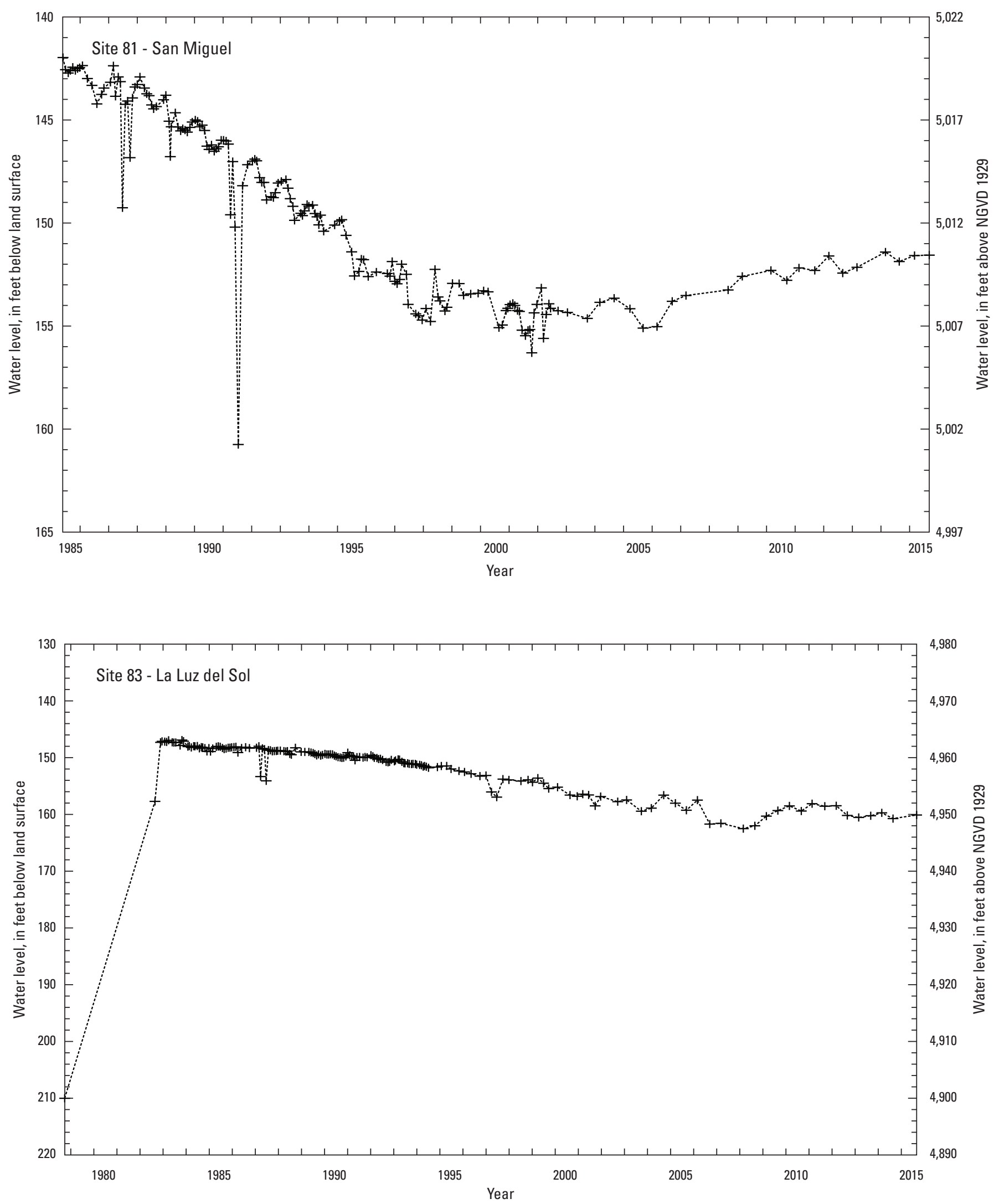

Figure 4. Water-level data for selected wells and piezometers in the Albuquerque Basin, central New Mexico, period of record through September 30, 2015 (NGVD 29, National Geodetic Vertical Datum of 1929).-Continued 

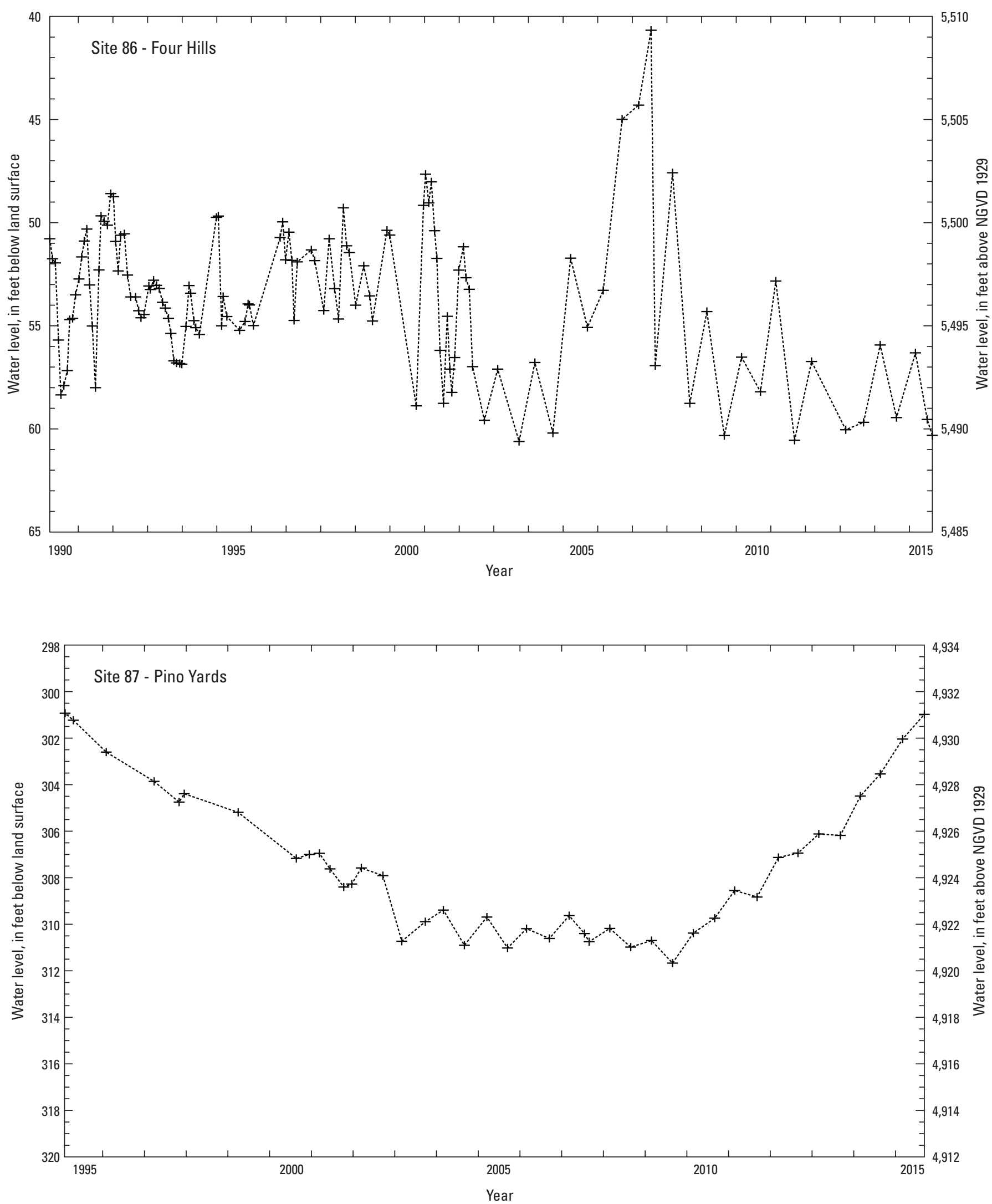

Figure 4. Water-level data for selected wells and piezometers in the Albuquerque Basin, central New Mexico, period of record through September 30, 2015 (NGVD 29, National Geodetic Vertical Datum of 1929).-Continued 

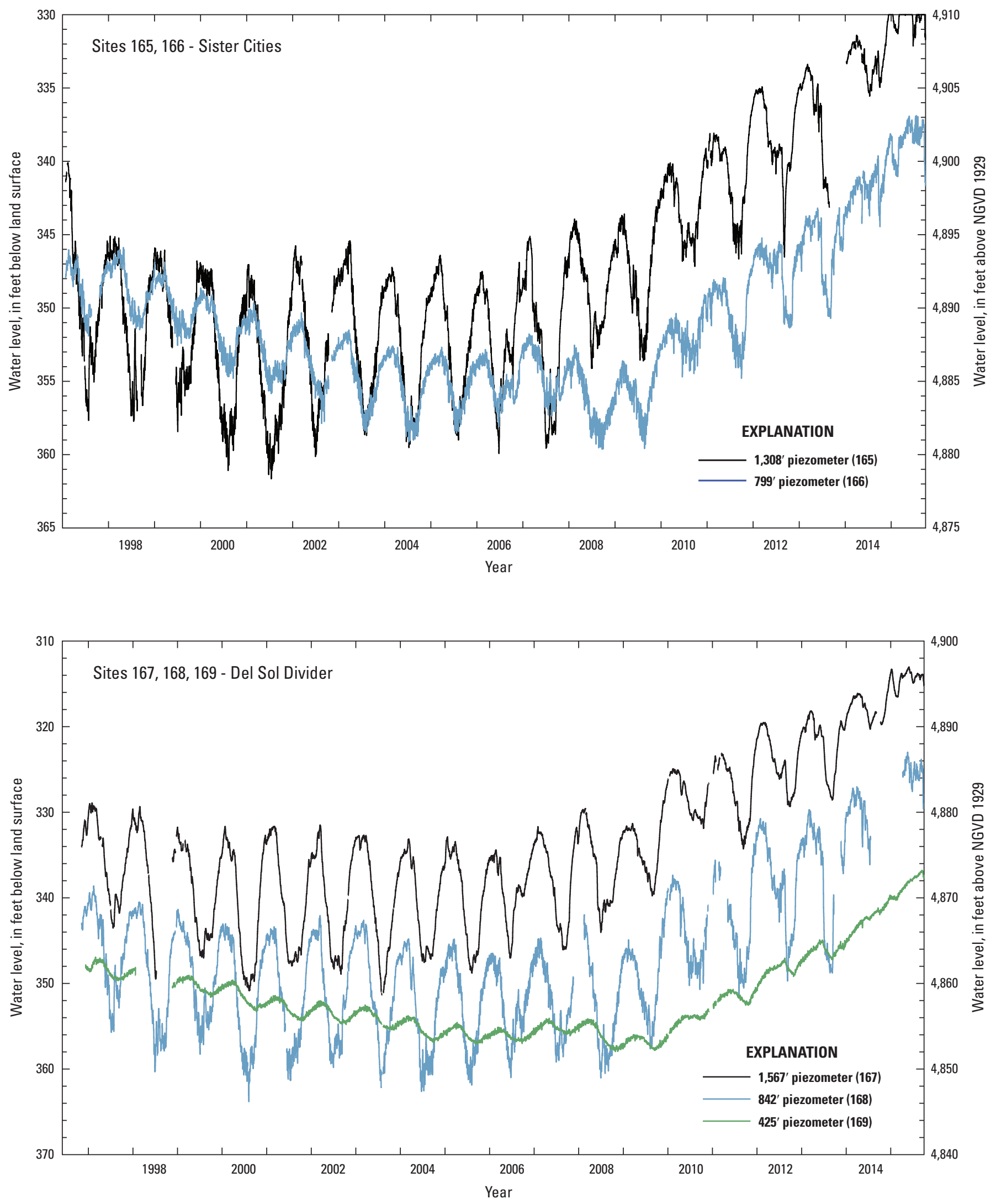

Figure 4. Water-level data for selected wells and piezometers in the Albuquerque Basin, central New Mexico, period of record through September 30, 2015 (NGVD 29, National Geodetic Vertical Datum of 1929).-Continued 

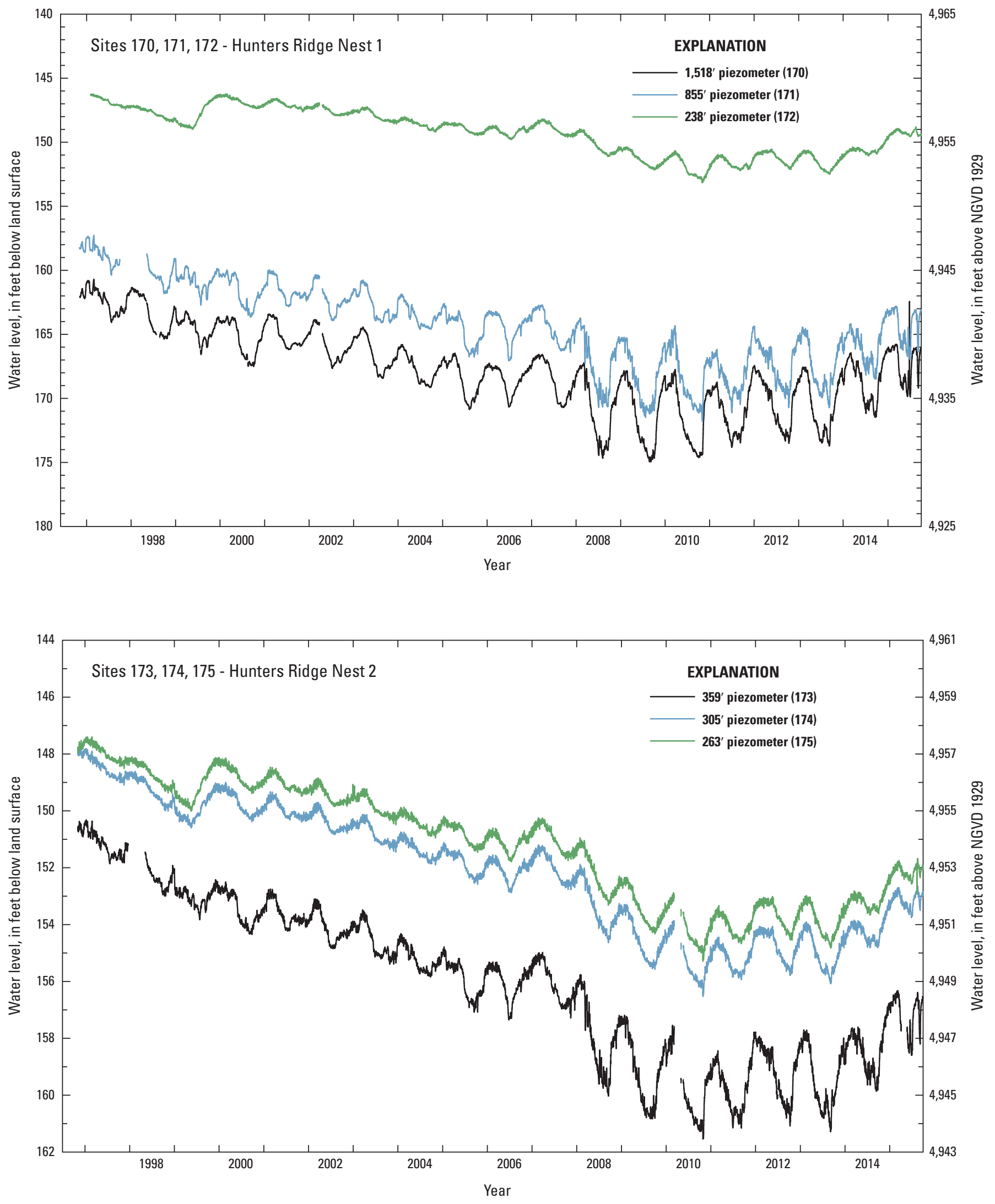

Figure 4. Water-level data for selected wells and piezometers in the Albuquerque Basin, central New Mexico, period of record through September 30, 2015 (NGVD 29, National Geodetic Vertical Datum of 1929).-Continued 

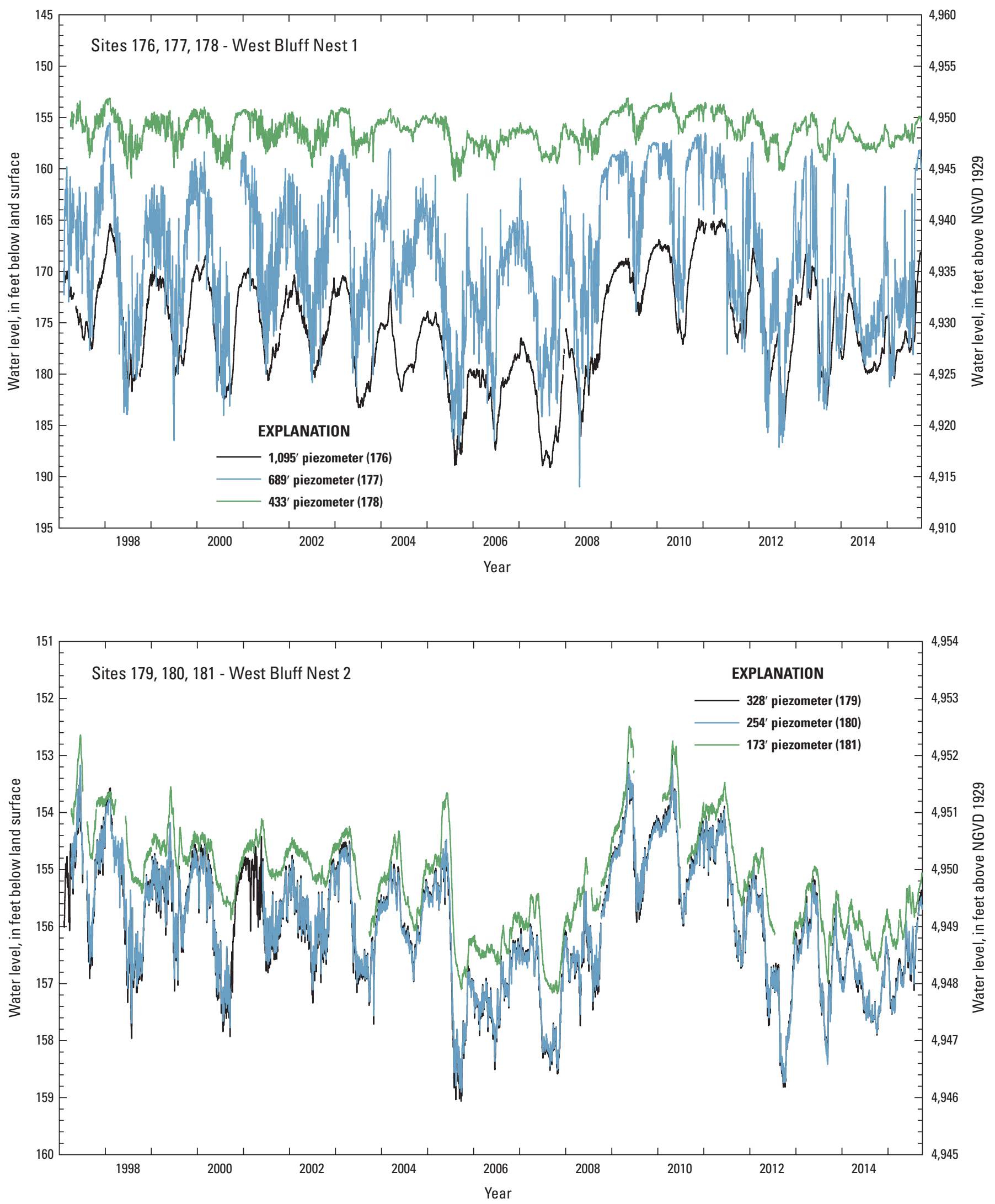

Figure 4. Water-level data for selected wells and piezometers in the Albuquerque Basin, central New Mexico, period of record through September 30, 2015 (NGVD 29, National Geodetic Vertical Datum of 1929)._Continued 

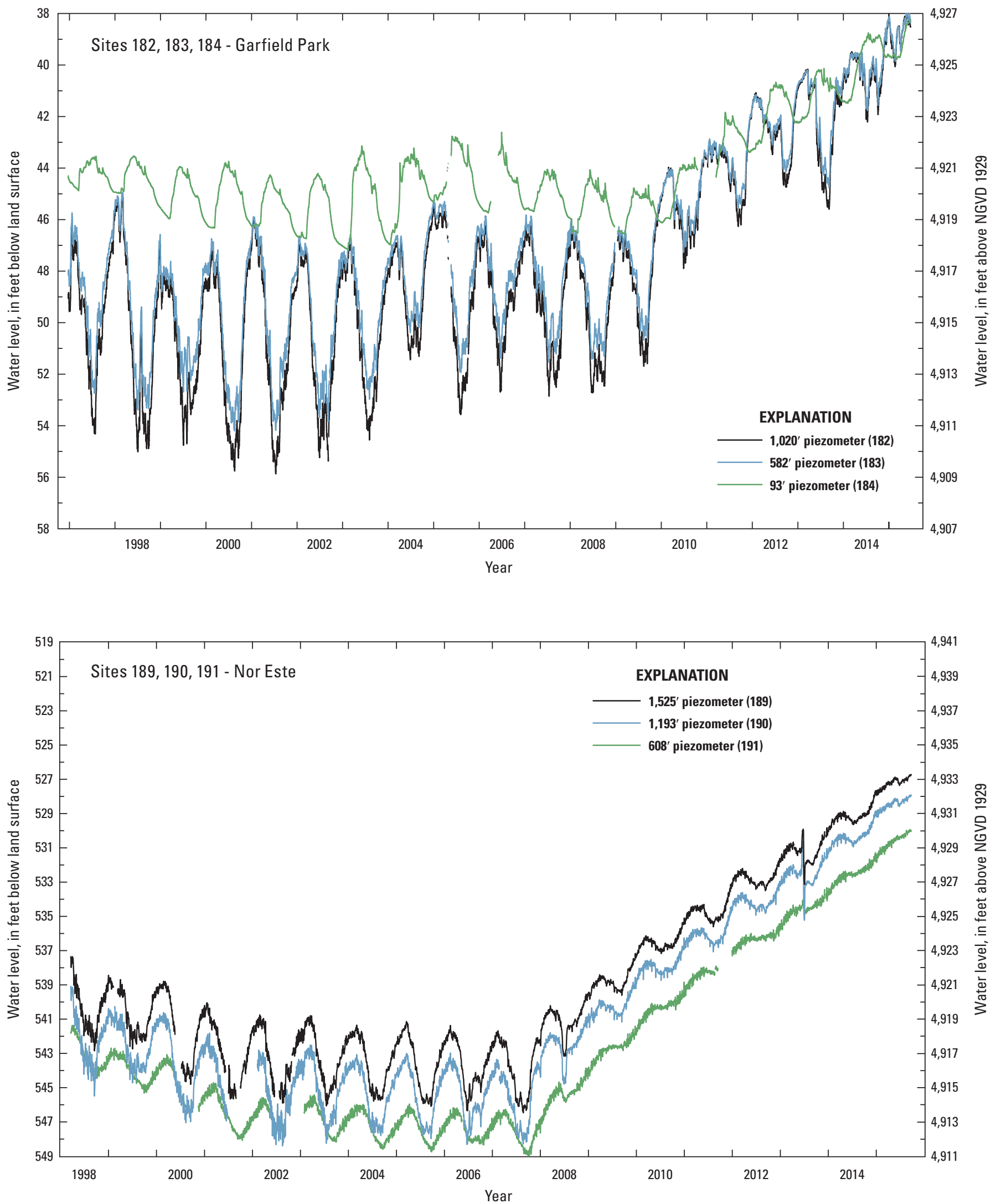

Figure 4. Water-level data for selected wells and piezometers in the Albuquerque Basin, central New Mexico, period of record through September 30, 2015 (NGVD 29, National Geodetic Vertical Datum of 1929).-Continued 

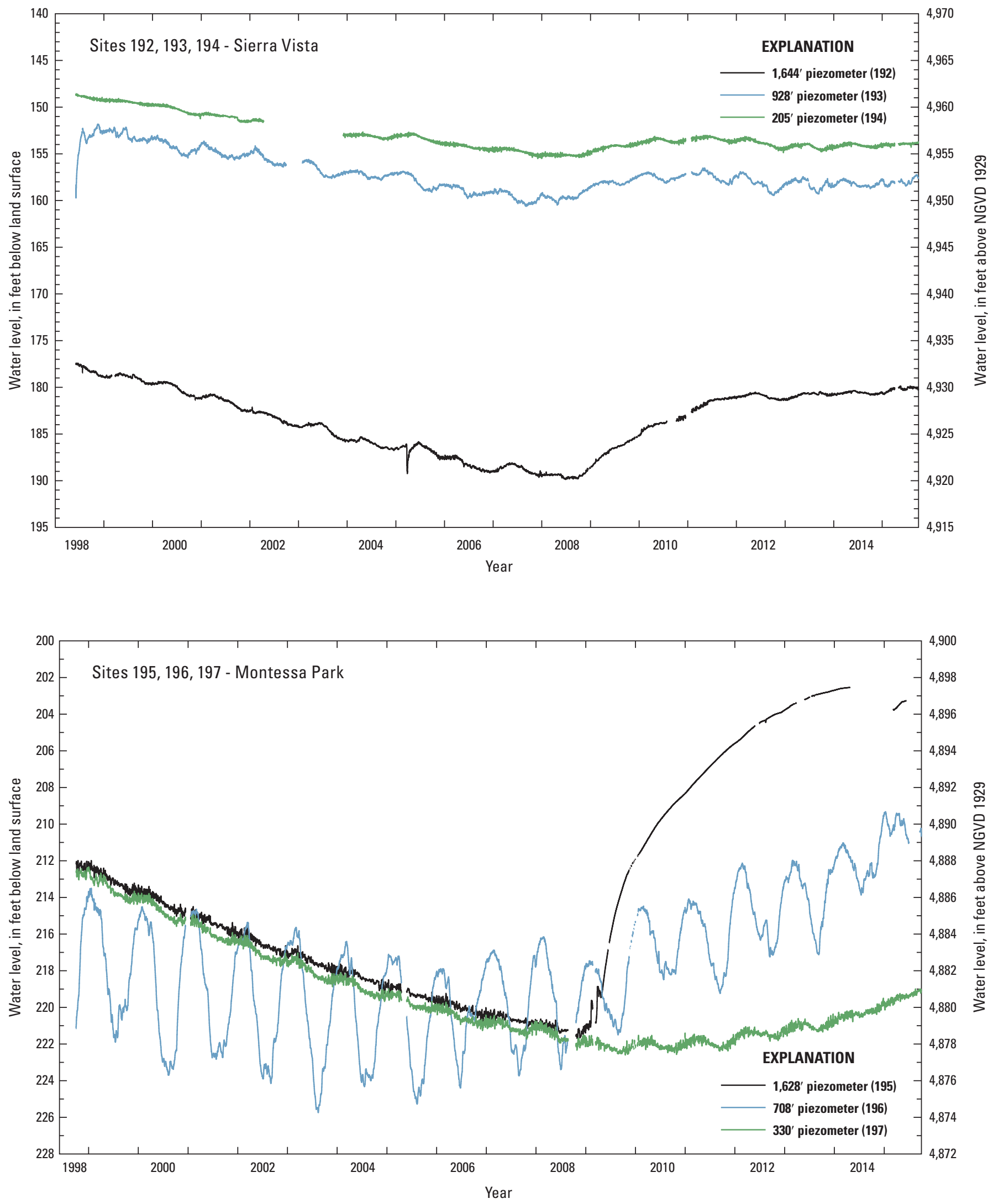

Figure 4. Water-level data for selected wells and piezometers in the Albuquerque Basin, central New Mexico, period of record through September 30, 2015 (NGVD 29, National Geodetic Vertical Datum of 1929)._Continued 

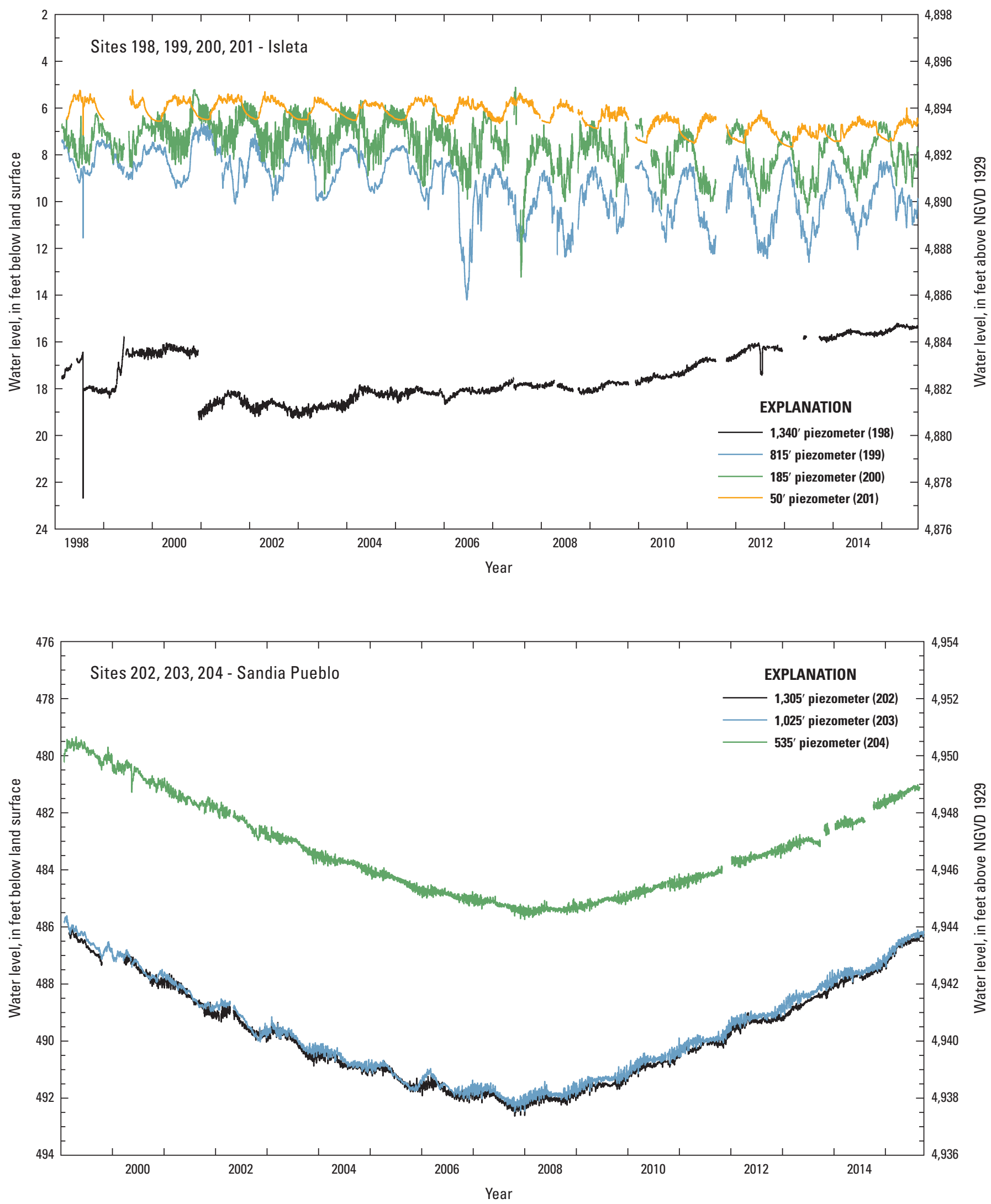

Figure 4. Water-level data for selected wells and piezometers in the Albuquerque Basin, central New Mexico, period of record through September 30, 2015 (NGVD 29, National Geodetic Vertical Datum of 1929).-Continued 

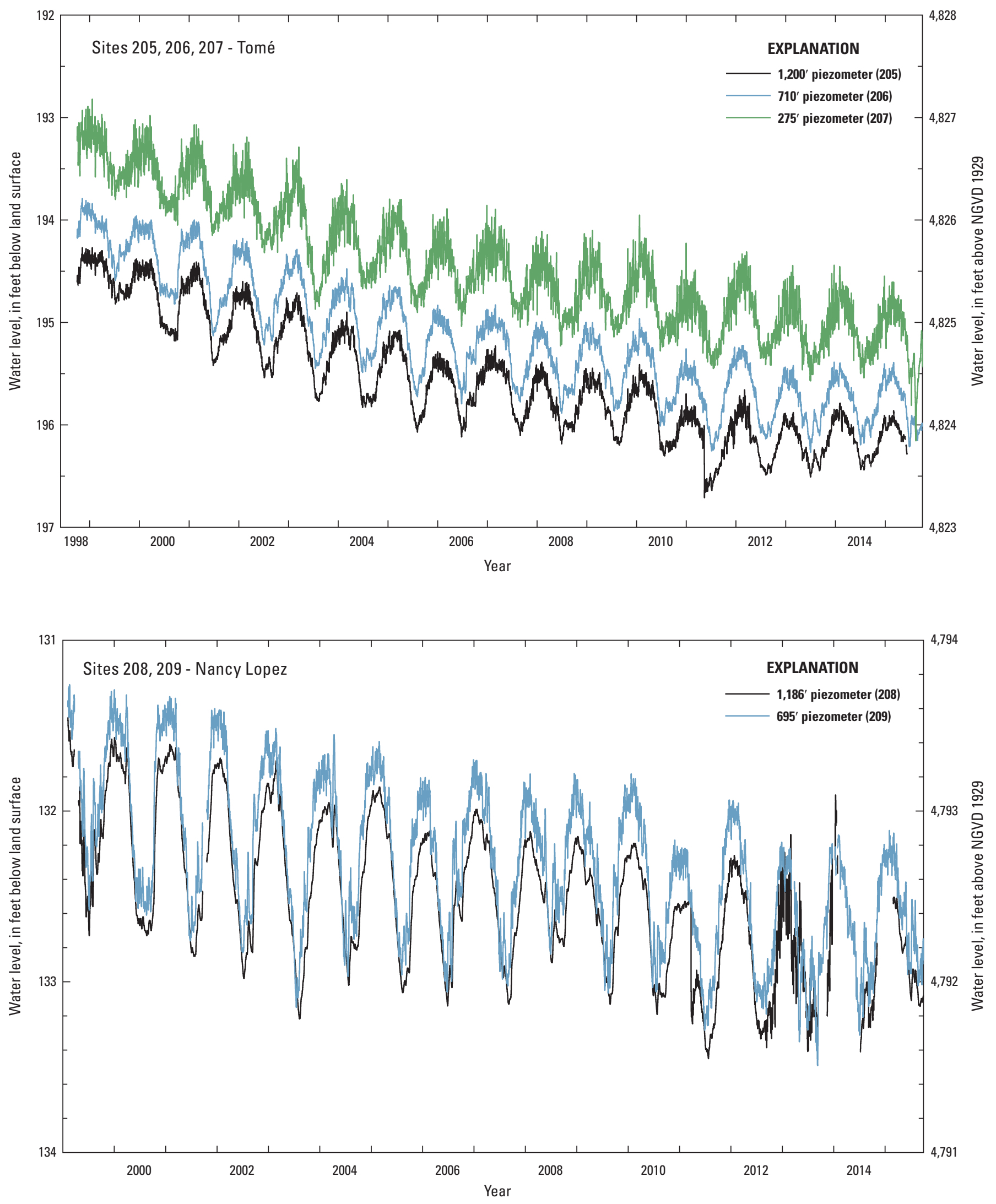

Figure 4. Water-level data for selected wells and piezometers in the Albuquerque Basin, central New Mexico, period of record through September 30, 2015 (NGVD 29, National Geodetic Vertical Datum of 1929).-Continued 

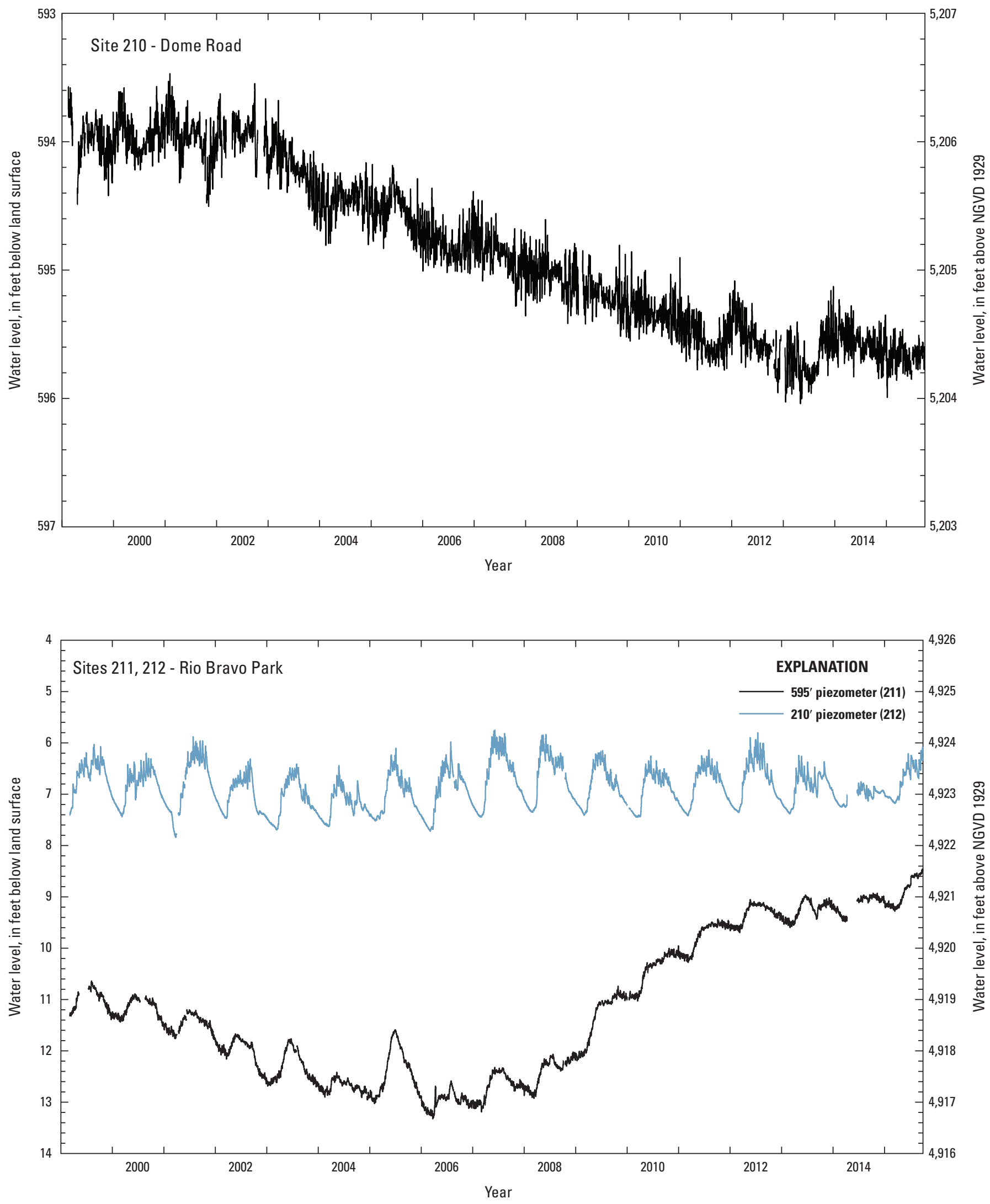

Figure 4. Water-level data for selected wells and piezometers in the Albuquerque Basin, central New Mexico, period of record through September 30, 2015 (NGVD 29, National Geodetic Vertical Datum of 1929).-Continued 

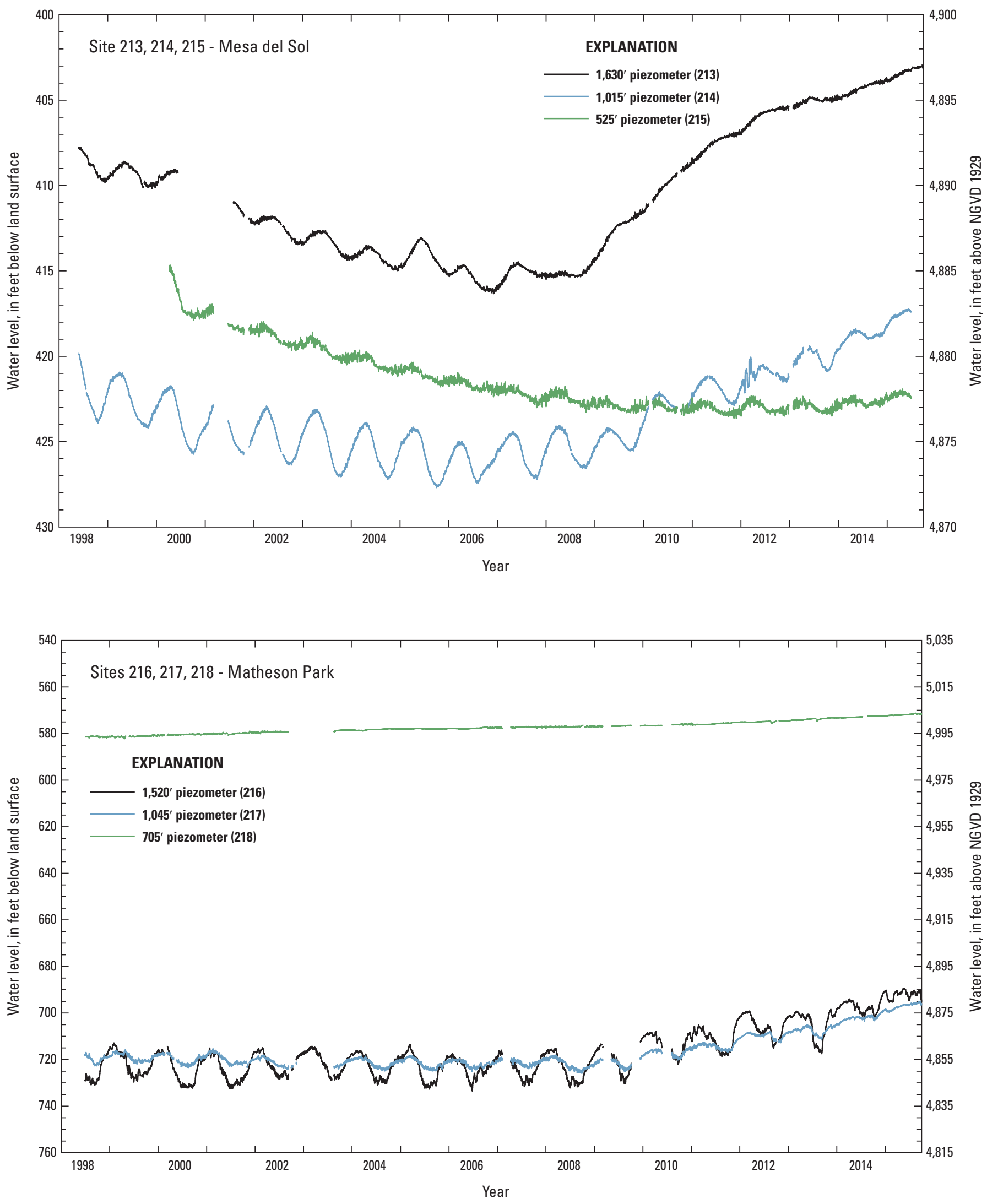

Figure 4. Water-level data for selected wells and piezometers in the Albuquerque Basin, central New Mexico, period of record through September 30, 2015 (NGVD 29, National Geodetic Vertical Datum of 1929).-Continued 

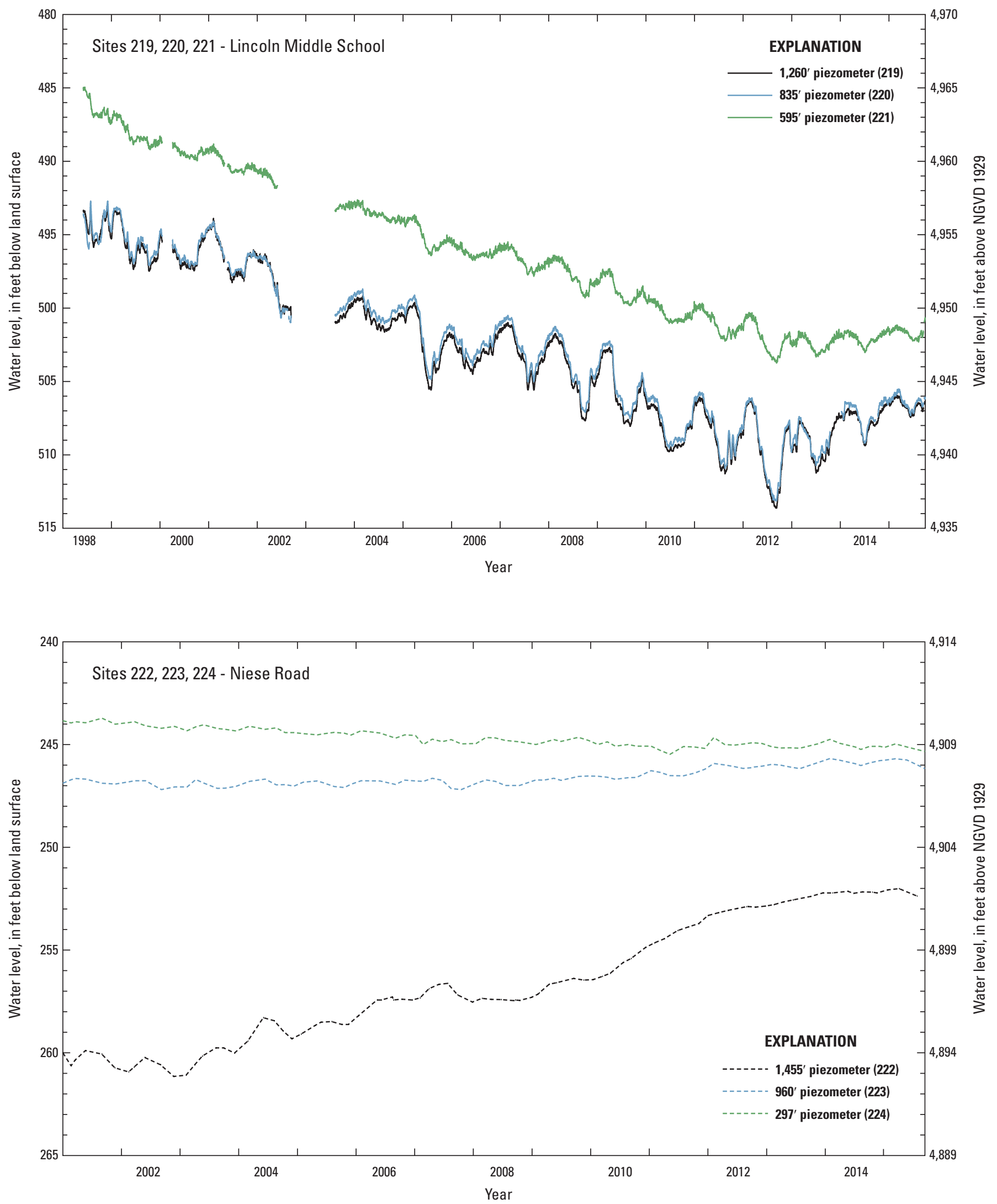

Figure 4. Water-level data for selected wells and piezometers in the Albuquerque Basin, central New Mexico, period of record through September 30, 2015 (NGVD 29, National Geodetic Vertical Datum of 1929).-Continued 

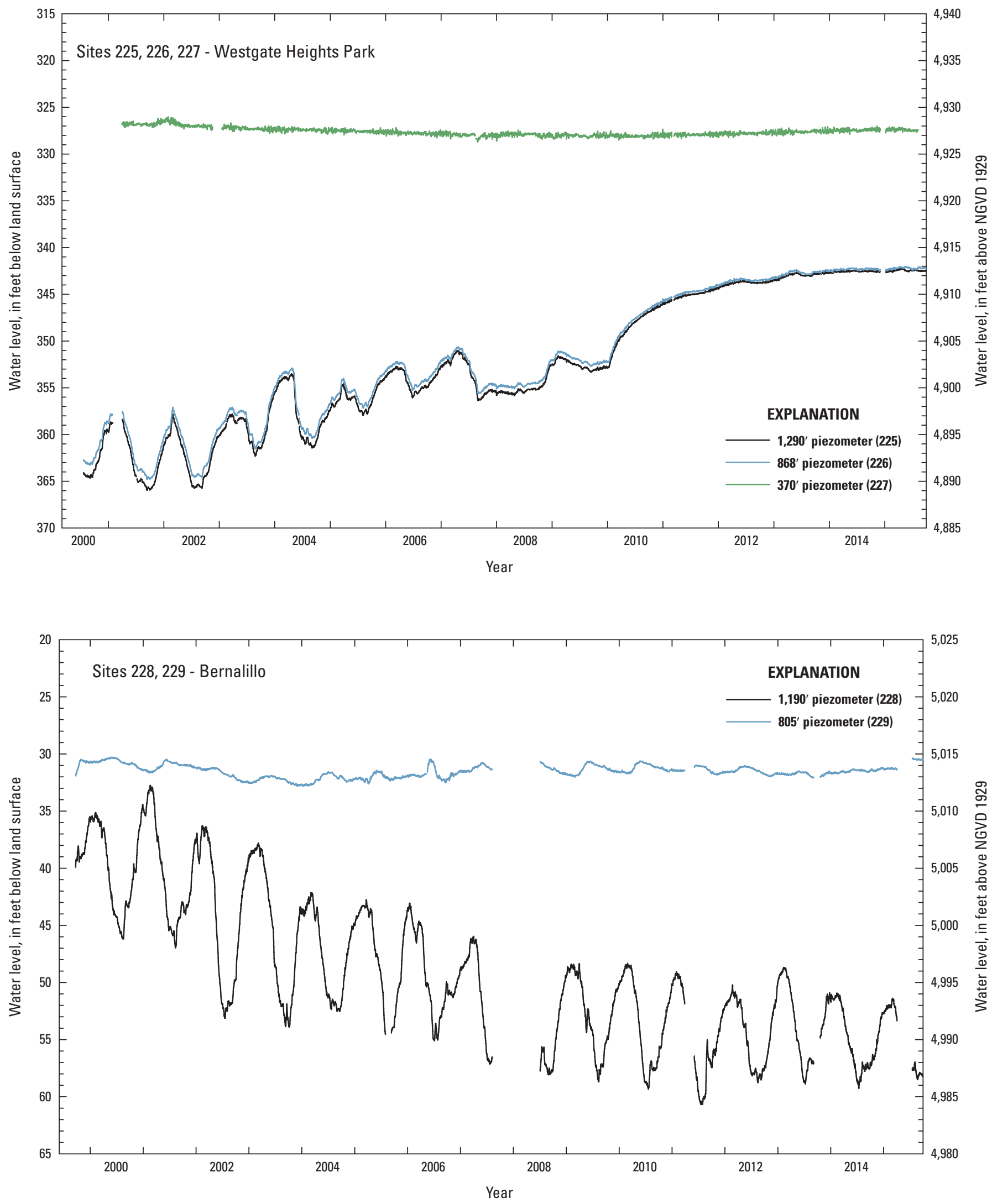

Figure 4. Water-level data for selected wells and piezometers in the Albuquerque Basin, central New Mexico, period of record through September 30, 2015 (NGVD 29, National Geodetic Vertical Datum of 1929)._Continued 

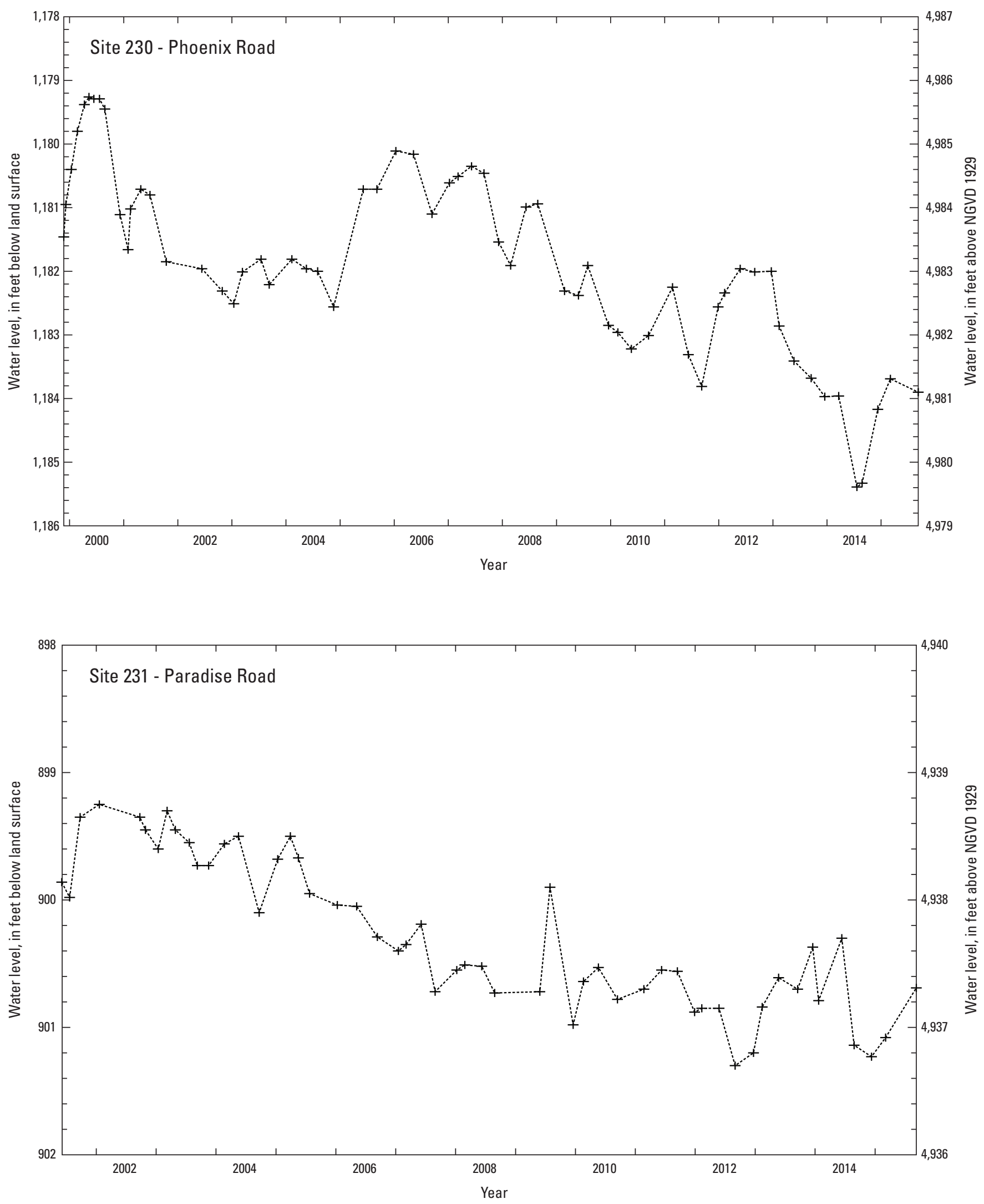

Figure 4. Water-level data for selected wells and piezometers in the Albuquerque Basin, central New Mexico, period of record through September 30, 2015 (NGVD 29, National Geodetic Vertical Datum of 1929)._-Continued 

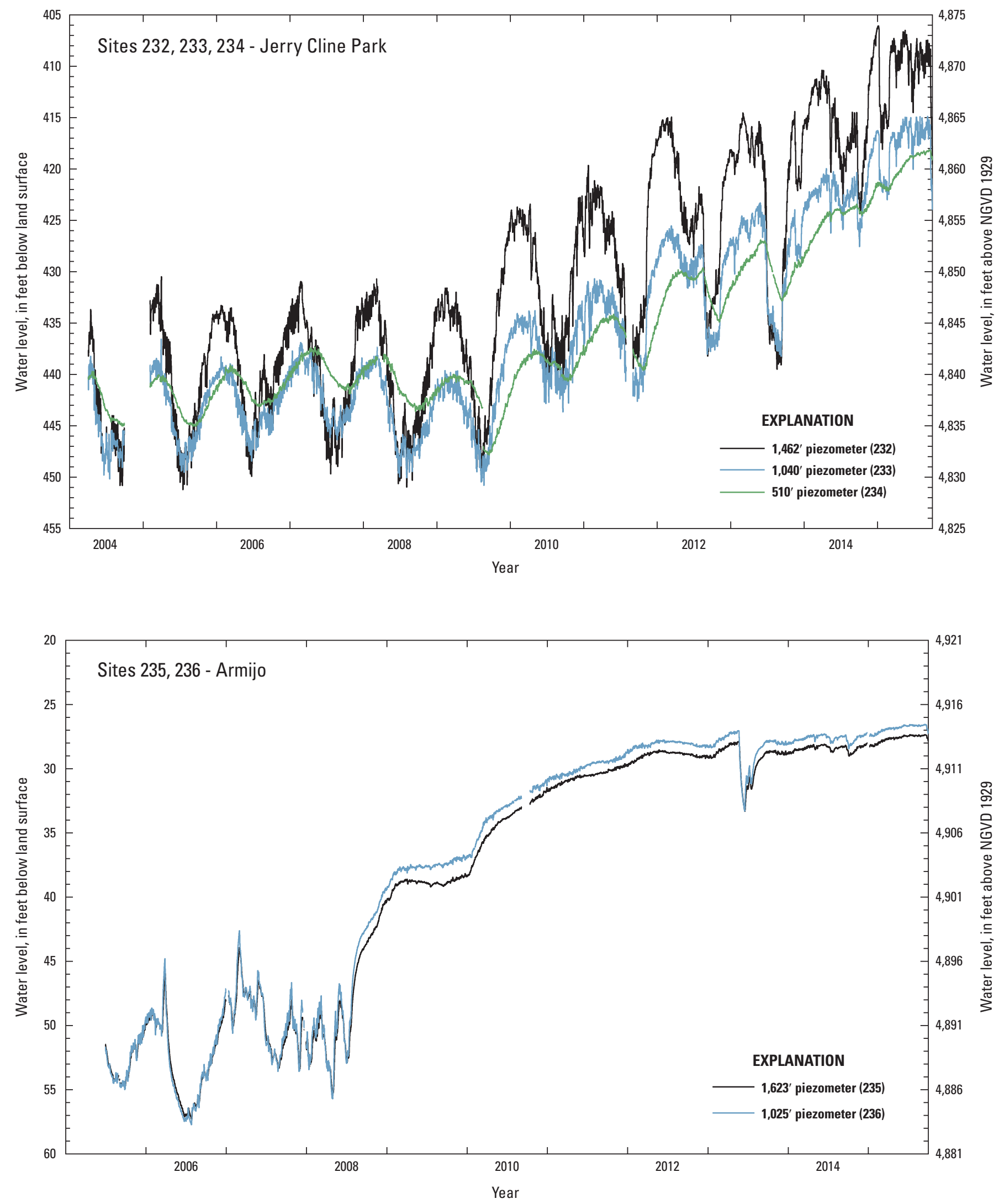

Figure 4. Water-level data for selected wells and piezometers in the Albuquerque Basin, central New Mexico, period of record through September 30, 2015 (NGVD 29, National Geodetic Vertical Datum of 1929)._Continued 


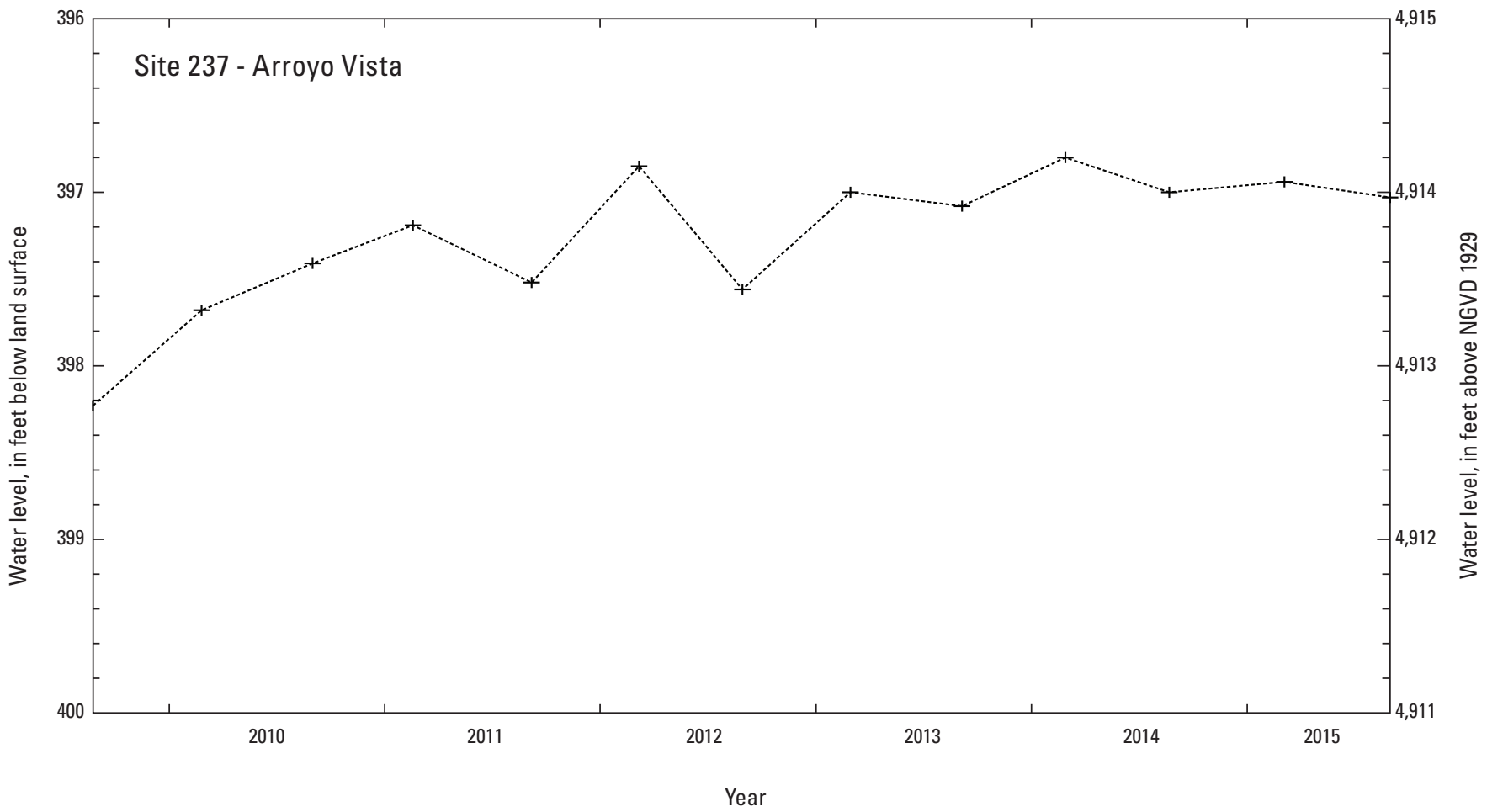

Figure 4. Water-level data for selected wells and piezometers in the Albuquerque Basin, central New Mexico, period of record through September 30, 2015 (NGVD 29, National Geodetic Vertical Datum of 1929).-Continued 


\section{References Cited}

Bartolino, J.R., and Cole, J.C., 2002, Ground-water resources of the Middle Rio Grande Basin, New Mexico: U.S. Geological Survey Circular 1222, 132 p. [Also available at http://pubs.usgs.gov/circ/2002/circ1222/.]

Beman, J.E., 2007, Water-level data for the Albuquerque Basin and adjacent areas, central New Mexico, period of record through September 30, 2006: U.S. Geological Survey OpenFile Report 2007-1273, 34 p. [Also available at http://pubs. usgs.gov/of/2007/1273/.]

Beman, J.E., 2008, Water-level data for the Albuquerque Basin and adjacent areas, central New Mexico, period of record through September 30, 2007: U.S. Geological Survey OpenFile Report 2008-1255, 32 p. [Also available at http://pubs. usgs.gov/of/2008/1255/.]

Beman, J.E., 2009, Water-level data for the Albuquerque Basin and adjacent areas, central New Mexico, period of record through September 30, 2008: U.S. Geological Survey OpenFile Report 2009-1125, 37 p. [Also available at http://pubs. usgs.gov/of/2009/1125/.]

Beman, J.E., 2011, Water-level data for the Albuquerque Basin and adjacent areas, central New Mexico, period of record through September 30, 2010: U.S. Geological Survey Data Series 623, 28 p. [Also available at http://pubs.usgs.gov/ ds/623/.]

Beman, J.E., 2012, Water-level data for the Albuquerque Basin and adjacent areas, central New Mexico, period of record through September 30, 2011: U.S. Geological Survey Data Series 714, 29 p. [Also available at http://pubs.usgs.gov/ ds/714/.]

Beman, J.E., 2013, Water-level data for the Albuquerque Basin and adjacent areas, central New Mexico, period of record through September 30, 2012: U.S. Geological Survey Data Series 790, 28 p. [Also available at http://pubs.usgs.gov/ ds/790/.]

Beman, J.E., 2014, Water-level data for the Albuquerque Basin and adjacent areas, central New Mexico, period of record through September 30, 2013: U.S. Geological Survey Data Series 873, 40 p. [Also available at http://pubs.usgs.gov/ ds/873/.]

Beman, J.E., 2015, Water-level data for the Albuquerque Basin and adjacent areas, central New Mexico, period of record through September 30, 2014: U.S. Geological Survey Data Series 963, 42 p. [Also available at http://pubs.er.usgs.gov/ publication/ds963.]
Beman, J.E., and Torres, L.T., 2010, Water-level data for the Albuquerque Basin and adjacent areas, central New Mexico, period of record through September 30, 2009: U.S. Geological Survey Open-File Report 2010-1228, 31 p. [Also available at http://pubs.usgs.gov/of/2010/1228/.]

Cunningham, W.L., and Schalk, C.W., comps., 2011, Groundwater technical procedures of the U.S. Geological Survey: U.S. Geological Survey Techniques and Methods 1-A1, 151 p., accessed September 30, 2014, at http://pubs. usgs.gov/tm/1a1/.

DeWees, R.K., 2001, Water-level data for the Albuquerque Basin and adjacent areas, central New Mexico, period of record through 2000: U.S. Geological Survey Open-File Report 2001-184, 62 p. [Also available at http://pubs. er.usgs.gov/publication/ofr01184.]

DeWees, R.K., 2002, Water-level data for the Albuquerque Basin and adjacent areas, central New Mexico, period of record through 2001: U.S. Geological Survey Open-File Report 2002-312, 41 p. [Also available at http://pubs. er.usgs.gov/publication/ofr02312.]

DeWees, R.K., 2003, Water-level data for the Albuquerque Basin and adjacent areas, central New Mexico, period of record through 2002: U.S. Geological Survey Open-File Report 2003-321, 41 p. [Also available at http://pubs. er.usgs.gov/publication/ofr03321.]

DeWees, R.K., 2006, Water-level data for the Albuquerque Basin and adjacent areas, central New Mexico, period of record through 2004: U.S. Geological Survey Open-File Report 2006-1281, 40 p. [Also available at http://pubs.usgs. gov/of/2006/1281/.]

Kues, G.E., 1987, Ground-water-level data for the Albuquerque-Belen Basin, New Mexico, through water year 1985: U.S. Geological Survey Open-File Report 87-116, 51 p. [Also available at http://pubs.er.usgs.gov/publication/ ofr87116.]

Rankin, D.R., 1994, Water-level data for the Albuquerque Basin, New Mexico, October 1, 1986, through September 30, 1990: U.S. Geological Survey Open-File Report 94-349, 29 p. [Also available at http://pubs.er.usgs.gov/ publication/ofr94349.]

Rankin, D.R., 1996, Water-level data for the Albuquerque Basin, New Mexico, period of record through September 30, 1995: U.S. Geological Survey Open-File Report 96-664A, 28 p. [Also available at http://pubs.er.usgs.gov/ publication/ofr96664A.] 
Rankin, D.R., 1998, Water-level data for the Albuquerque Basin, central New Mexico, period of record through 1997: U.S. Geological Survey Open-File Report 98-408, 28 p. [Also available at http://pubs.er.usgs.gov/publication/ ofr98408.]

Rankin, D.R., 1999, Water-level data for the Albuquerque Basin and adjacent areas, New Mexico, period of record through 1998: U.S. Geological Survey Open-File Report 99-269, 27 p. [Also available at http://pubs.er.usgs.gov/ publication/ofr99269.]

Rankin, D.R., 2000, Water-level data for the Albuquerque Basin and adjacent areas, central New Mexico, period of record through 1999: U.S. Geological Survey Open-File Report 2000-231, 62 p. [Also available at http://pubs. er.usgs.gov/publication/ofr00231.]

Thorn, C.R., McAda, D.P., and Kernodle, J.M., 1993, Geohydrologic framework and hydrologic conditions in the Albuquerque Basin, central New Mexico: U.S. Geological Survey Water-Resources Investigations Report 93-4149, 106 p. [Also available at http://pubs.er.usgs.gov/publication/ wri934149.]

U.S. Census Bureau, 2001, State and county quickfacts: Accessed July 15, 2002, at http://quickfacts.census.gov.

U.S. Census Bureau, 2011a, 2010 census centers of population by census tract, updated March 12, 2013: Accessed April 18, 2013, at http://www.census.gov/geo/reference/ centersofpop.html.

U.S. Census Bureau, 2011b, State and county quickfacts for Albuquerque (city), New Mexico: Accessed April 18, 2013, at http://quickfacts.census.gov/qfd/states/35/3502000.html. 
Publishing support provided by Lafayette Publishing Service Center 



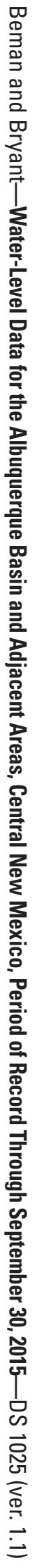

